\title{
Outdoor thermal comfort and summer PET range: A field study in tropical city Dhaka
} Tania Sharmin $^{\mathrm{a}, 1}$, Koen Steemers ${ }^{2}$ and Michael Humphreys ${ }^{3}$

\begin{abstract}
Urban microclimate has important consequences on the thermal sensation of pedestrians. However, the extent of this effect may vary as other parameters such as respondents' personal factors, psychological and behavioural aspects and cultural backgrounds may be involved. This heightens the need for subjective assessment and on-site questionnaire surveys alongside objective field measurements to understand outdoor comfort conditions which is essential for creating sustainable urban spaces. In this study thermal comfort conditions outdoors are examined through field surveys in the high-density, tropical city Dhaka, where extensive microclimatic monitoring has been carried out in parallel to subjective responses of the pedestrians. Microclimatic conditions, which are affected by the urban geometry, are found to be statistically correlated with thermal sensation votes (TSV), with air temperature, globe temperature and mean radiant temperature being the most important parameters (correlation coefficients of $\mathrm{r}=0.47,0.45$ and 0.44 respectively). The study also reports the effect of urban geometry parameters on microclimatic conditions, identifying strong correlations with globe temperature $(\mathrm{r}=-0.50)$, mean radiant temperature $(\mathrm{r}=-0.48)$ and wind speed $(\mathrm{r}=0.72)$. Furthermore, the study proposes acceptable ranges (upper limits) for PET for the tropical climate of Dhaka with a 'Neutral' range between $29.5^{\circ}-32.5^{\circ} \mathrm{C}$ confirming that people in outdoor conditions will feel comfortable at a higher PET range.
\end{abstract}

Keywords: Outdoor thermal comfort; Thermal Sensation Vote (TSV); PET analysis; Tropical climate

\section{Introduction}

Outdoor thermal comfort has become an increasingly important topic in the context of a global trend towards unbridled urbanisation. Due to global warming, heat island effect, air pollution and declining green areas, the microclimate in high-density cities in the tropics is rapidly deteriorating. A worsening of microclimatic conditions can have serious consequences on the health and wellbeing of people who use outdoor spaces within a city. Yet relatively little research has been conducted regarding the microclimate in tropical cities (Oke, Taesler and Olsson, 1990; Villadiego and Velay-Dabat, 2014; Fong et al., 2019). The majority of the thermal comfort research concentrates on temperate and cold climate, although people in these climates tend to spend most of their times indoors compared to tropical climate. For example, in the United States and Canada, on average people only spend $2-4 \%$ of their time in outdoors during winter and 10\% in summer (Salata et al., 2016). Research on temperate climate include: Nikolopoulou, Baker and Steemers, 2001; Zacharias, Stathopoulos and $\mathrm{Wu}, 2001,2004$; Thorsson, Lindqvist and Lindqvist, 2004; Nikolopoulou

\footnotetext{
${ }^{1}$ Architecture Research Institute, Leicester School of Architecture, De Montfort University, Leicester LE1 9BH, UK.

${ }^{\mathrm{a}}$ Corresponding author: tania.sharmin@dmu.ac.uk

2 The Martin Centre for Architectural and Urban Studies, University of Cambridge, UK.

${ }^{3}$ Faculty of Technology, Design and Environment, Oxford Brookes University
} 
and Lykoudis, 2006, 2007; Eliasson et al., 2007; Thorsson et al., 2007; Taleghani et al., 2014 etc. Numerous studies have been conducted in the hot-dry climate (Ali-Toudert, 2005; Johansson, 2006; Ali-Toudert and Mayer, 2007b, 2007a; Yahia and Johansson, 2013) and some in a subtropical climate (Lin and Matzarakis, 2008; Lin, Matzarakis and Hwang, 2010; Cheng et al., 2012; $\mathrm{Ng}$ and Cheng, 2012). Important studies in a tropical climate include Ahmed, 2003; Emmanuel and Johansson, 2006; Emmanuel, Rosenlund and Johansson, 2007; Yang, Wong and Jusuf, 2013; Villadiego and Velay-Dabat, 2014; Ignatius, Wong and Jusuf, 2015 etc. These studies provide an extensive knowledge of the effects of outdoor climatic conditions on people's thermal sensation. Nevertheless, people's thermal comfort sensation can be quite diversified depending on the climate and microclimate of the city they live in and their cultural backgrounds (Salata et al., 2016). The context of each city is unique and therefore, it is important to conduct field studies in different cities to complement our existing knowledge towards making healthy cities.

This study examines the impact of urban microclimate on outdoor thermal comfort. One approach to exploring the impact is to investigate the statistical correlation between the environmental conditions and subjective thermal sensation vote measured simultaneously. This approach is adopted in this study. However, it is not always easy to see a straightforward association between microclimate and thermal sensation in real-life examples as people's thermal comfort in outdoor spaces cannot be fully explained by environmental conditions alone (Nikolopoulou \& Steemers, 2003). Villadiego \& Velay-Dabat (2014) have reported a weak correlation between thermal sensation vote and air temperature $(\mathrm{r}=0.31)$, relative humidity $(\mathrm{r}=\mathrm{-}$ 0.12) and wind speed $(\mathrm{r}=$ null). Nikolopoulou \& Lykoudis (2006), in their study across different European countries, have found slightly higher correlations with air temperature $(r=0.43)$ and globe temperature $(r=0.53)$, yet advised that independent microclimatic parameters are unable to explain all variations in outdoor comfort conditions. Despite the limitations, this approach is better in examining the effect of urban form on pedestrian comfort as this deals with the complexity of the real outdoor situations, where people's comfort sensation can be quite diversified.

An alternative approach is to apply a standard thermal index to artificially calculate thermal sensation of the people and compare this with the objective measurements. This comprises calculating the value of thermal sensation using the thermal index and then correlating these predicted sensations against microclimatic variables. In this way, a higher correlation can be achieved between microclimatic conditions and thermal sensation. However, most of the available indices are developed for a particular context and often unable to consider detailed personal and psychological influences which may be as equally important as environmental conditions.

Urban microclimate is affected by the configuration and orientation of the streets, heights of the flanking buildings and associated features (Krüger, Minella and Rasia, 2011). Several studies (Emmanuel, Rosenlund and Johansson, 2007; Lin, Matzarakis and Hwang, 2010) have examined the direct association between common urban geometry parameters, such as the H/W ratio (Height/ Width ratio) or SVF (Sky View Factor) and thermal comfort sensations using PET (Physiologically Equivalent Temperature) thermal index. Lin et al. (2010) have applied the RayMan model (Matzarakis, Rutz and Mayer, 2010) for predicting long-term thermal comfort on a university campus in central Taiwan $\left(23^{\circ} 42^{\prime} \mathrm{N}, 120^{\circ} 26^{\prime} \mathrm{E}\right.$, 
$23 \mathrm{~m}$ a.s.1. (above sea level)) using PET. On the other hand, (Emmanuel, Rosenlund and Johansson, 2007) have adopted a numerical simulation method and reported a decrease in PET when the H/W ratio is increased from 1 to 3 in tropical climate in Colombo, Sri Lanka $\left(6^{0} 9^{\prime} \mathrm{N}, 79^{0} 9^{\prime} \mathrm{E}, 7 \mathrm{~m}\right.$ a.s.1.). Thus, narrow streets were identified as providing better shading for the pedestrians compared to wide streets. Bourbia \& Awbi (2004) in a theoretical study have simulated the shading conditions by combining different $\mathrm{H} / \mathrm{W}$ ratios with various street orientations and tree positions for hot-dry climate at latitude $33^{\circ} \mathrm{N}$. Ali-Toudert \& Mayer (2007a) have examined the effects of galleries and overhanging facades on the thermal comfort conditions of street canyons with different aspect ratios located under hot and dry climate in Ghardaia ( $32^{\circ} 40^{\prime} \mathrm{N}, 503 \mathrm{~m}$ a.s.1.) in the Algerian Sahara. They concluded that the appropriate choice of $\mathrm{H} / \mathrm{W}$-ratio and orientation can lead to a substantial amelioration of the microclimate at street level and thus create favourable comfort conditions for pedestrians.

Similar to H/W-ratios, the association of SVF with pedestrian thermal comfort was examined by a number of studies. Charalampopoulos et al. (2013) have carried out a thermal comfort analysis on the Mediterranean climate in Greece $\left(37^{0} 58^{\prime} \mathrm{N}, 23^{0} 43^{\prime} \mathrm{E}, 107 \mathrm{~m}\right.$ a.s.1.), in six different sites, each having distinctive SVF, physical configuration and vegetation coverage. The study has reported significant relationships between SVF and biometeorological indices (PET and Humidex). Ng \& Cheng (2012) have determined the outdoor comfort ranges for the sub-tropical Hong Kong $\left(22^{0} 31^{\prime}\right.$ N, $114^{0} 16^{\prime}$ E, $51 \mathrm{~m}$ a.s.l.) by running regression analysis between the objective climatic measurements and PET calculation.

To summarise, in all of the above studies, either microclimatic simulation techniques have been used and then, urban geometry characters are analysed through parametric studies; or, where a real urban configuration is used, a mathematical thermal index (mostly PET) has been applied in order to understand the relationship between urban geometry and thermal sensation of the pedestrians. In a way, these studies undermine the diversity of thermal sensation at outdoor urban spaces. Not every study has attempted to establish a direct link between the actual thermal sensation collected through a questionnaire survey and microclimatic parameters measured at the real urban canyons. Fong et al. (2019) have reviewed 21 studies on outdoor thermal comfort research in Southeast Asia and half of them did not use subjective assessment in their studies despite its significance to address thermal comfort conditions at individual levels. Consequently, this study examines the correlations between the microclimatic variables and the actual thermal comfort votes collected during the survey to understand the way urban microclimate affects thermal comfort in a tropical context.

The study has been structured in two stages. Firstly, it starts with an analysis of microclimate attributable to the urban form, and then, goes on to extract the relation between PET and thermal sensation, acceptability etc. The causation is like this: Dhaka modifies the local climate- the built form further modifies it - people respond to the microclimate as measured in the streets they are actually in. 


\section{Methodology}

\subsection{Study area}

Dhaka is located at $23^{0} .24^{\prime} \mathrm{N}, 90^{\circ} .23^{\prime} \mathrm{E}$ with an elevation between 2 to $14 \mathrm{~m}$ above sea level (a.s.1.) with an average of 6.5 m (JICA, 1987, cited in (Rahman, Siddiqua and Kamal, 2015)). The city has a tropical hot-humid climate and falls under the tropical savanna climate' as per the Köppen climate classification (Köppen, 1931; Ahmed et al., 2014). It has three main seasons: the pre-monsoon hot season (hot-dry, from March - May), the monsoon season (hot-humid, from June - October) and a brief cool-dry season (from December February). According to the EPW (EnergyPlus Weather) (http://apps1.eere.energy.gov/buildings/energyplus/) data for Dhaka, the mean annual temperature is $25.8^{\circ} \mathrm{C}$ with an annual range between $39.4^{\circ} \mathrm{C}$ to $8.2^{\circ} \mathrm{C}$. April is the hottest month with average maximum temperatures exceeding $37.5^{\circ} \mathrm{C}$, while January is the coolest with a mean monthly temperature of $18.5^{\circ} \mathrm{C}$. The mean annual relative humidity is $75 \%$. The mean hourly wind speed remains well below $4 \mathrm{~m} / \mathrm{s}$, with occasional gusts reaching up to 14 $\mathrm{m} / \mathrm{s}$. Dhaka receives a significant amount of solar radiation throughout the year. The average hourly maximum solar radiation exceeds $800 \mathrm{~W} / \mathrm{m}^{2}$ for almost $60 \%$ of the year. It is, however, rare to have clear-sky conditions in Dhaka throughout the day, except during the cool-dry season. During the hot-humid seasons, the sky remains predominantly overcast with brief clear spells. During the hot-dry season, a combination of clear sky and overcast conditions can be seen.

In total, eight urban canyons in six representative case study areas with different urban geometry characteristics have been chosen for the study (Figure 1). Case studies include four residential, one commercial and one educational area. The residential areas are of two types: traditional and formal. The traditional residential areas (TRA) are predominantly compact, high density urban areas with high aspect ratios, winding street patterns and varied building heights. Formal residential areas (FRA) also having compact built forms and a high-density settlement, have a lower aspect ratio with streets arranged in a grid-iron pattern and most importantly, a uniform building height. The traditional residential areas in this study are South Kafrul and Mid-Kafrul and the formal residential areas are Mahakhali DOHS and Baridhara DOHS, whereas the commercial area is Banani Commercial Area and the education area is TSC Shahbagh. The urban canyon names for this study and their orientation, abbreviated names and respective microclimatic site names are presented in Table 1. 
Table 1. Abbreviated site names

\begin{tabular}{|c|c|c|c|c|c|}
\hline $\begin{array}{l}\text { Urban canyon name and } \\
\text { orientation }\end{array}$ & $\begin{array}{l}\text { Microclimate } \\
\text { site name }\end{array}$ & $\begin{array}{l}\text { Abbreviated } \\
\text { name }\end{array}$ & \begin{tabular}{|l} 
sky view \\
factor
\end{tabular} & $\begin{array}{l}\text { canyon } \\
\text { aspect } \\
\text { ratio }\end{array}$ & $\begin{array}{l}\text { building height } \\
\text { range }(\mathrm{m}) \text { or, } \\
\text { mean height }\end{array}$ \\
\hline $\begin{array}{l}\text { Traditional Area } 1 \text { East- } \\
\text { West }\end{array}$ & South Kafrul & TRA1EW & \multirow[t]{2}{*}{$0.113-0.331$} & \multirow[t]{2}{*}{$1.0-4.0$} & \multirow[t]{2}{*}{$10-29$} \\
\hline $\begin{array}{l}\text { Traditional Area } 1 \text { North- } \\
\text { South }\end{array}$ & South Kafrul & TRA1NS & & & \\
\hline $\begin{array}{l}\text { Traditional Area } 2 \text { North- } \\
\text { South }\end{array}$ & Mid Kafrul & TRA2NS & $0.133-0.168$ & $1.8-3.5$ & $10-16$ \\
\hline Formal Area 1 East-West & Mahakhali DOHS & FRA1EW & $0.169-0.277$ & $2.0-2.5$ & 20 \\
\hline Formal Area 2 East-West & Baridhara DOHS & FRA2EW & \multirow[t]{2}{*}{$0.229-0.259$} & \multirow[t]{2}{*}{$1.2-1.8$} & \multirow[t]{2}{*}{20} \\
\hline Formal Area 2 North-South & Baridhara DOHS & FRA2NS & & & \\
\hline Commercial Area East-West & \begin{tabular}{|l|} 
Banani \\
commercial area
\end{tabular} & CAEW & $0.132-.179$ & $1.6-2.75$ & $32-62$ \\
\hline Educational Area & TSC Shahbagh & ECA & $0.447-0.756$ & $0.3-0.8$ & $10-20$ \\
\hline
\end{tabular}

\subsection{Microclimatic monitoring}

Meteorological measurements were carried out simultaneously with outdoor thermal comfort questionnaire surveys to analyse thermal comfort conditions and assess the effects of microclimatic environments. This was conducted for six days in September 2014 (autumn 2014) and five days in May and June in 2015 (summer 2015). The measurements were taken between 9:00-18:00. The measured microclimatic parameters included air temperature, globe temperature, relative humidity and wind speed. Air temperature and relative humidity were monitored using Tiny-tag data loggers placed inside solar radiation shields (Stevenson's screen), at a height of $1.1 \mathrm{~m}$ (representing the gravitational centre for an average height human body (ISO 7726, 1998)) in the case study urban canyons (Figure 2). The details (range and accuracy) of the instruments used in the study compared against ISO standards (ISO $7726,1998)$ is listed on Table 2. The questionnaire survey was conducted within a $3 \mathrm{~m}$ boundary of this measurement point assuming a consistent microclimatic condition within the boundary (Ng and Cheng, 2012; Spagnolo and de Dear, 2003). The measurement point was typically chosen around the middle of the length of the canyon so that the measurements are representative of the microclimatic conditions of the respective canyon. Thus, the effect of the neighbouring streets, and particularly street junctions, is slightly reduced. 
Table 2. Measuring range and accuracy for the instruments used Instruments in the study

\begin{tabular}{lll}
\hline Name of the current instrument & $\begin{array}{l}\text { Range of the } \\
\text { instrument }\end{array}$ & Accuracy of the instrument \\
\hline $\begin{array}{l}\text { Tinytag Ultra 2 } \\
\text { Temperature/ Relative Humidity Logger }\end{array}$ & -25 to $+85^{\circ} \mathrm{C}$ & Better than $\pm 0.5^{\circ} \mathrm{C}$ \\
\hline $\begin{array}{l}\text { Tinytag Plus 2 Temperature Logger for } \\
\text { Thermistor Probe PB-5001 }\end{array}$ & -40 to $+125^{\circ} \mathrm{C}$ & $\begin{array}{l}\text { Logger: Better than } \pm 0.35^{\circ} \mathrm{C} \text {, when } \\
\text { used with PB-5001 }\end{array}$ \\
\hline OM-CP-WIND101A-KIT Series & 0 to $100 \mathrm{MPH}(0$ & $\begin{array}{l} \pm 2.0 \mathrm{mph} \text { from } 0 \text { to } 10 \mathrm{mph} ; \pm 2.5 \% \text { of } \\
\text { reading from }>10 \text { to } 100 \mathrm{mph}\end{array}$ \\
\hline $\begin{array}{l}\text { to } 44.704 \mathrm{~m} / \mathrm{s}) \\
\text { Tinytag Ultra 2 }\end{array}$ & 0 to $95 \% \mathrm{RH}$ & $\pm 3.0 \% \mathrm{RH}$ at $25^{\circ} \mathrm{C} / 77^{\circ} \mathrm{F}$ \\
\hline
\end{tabular}

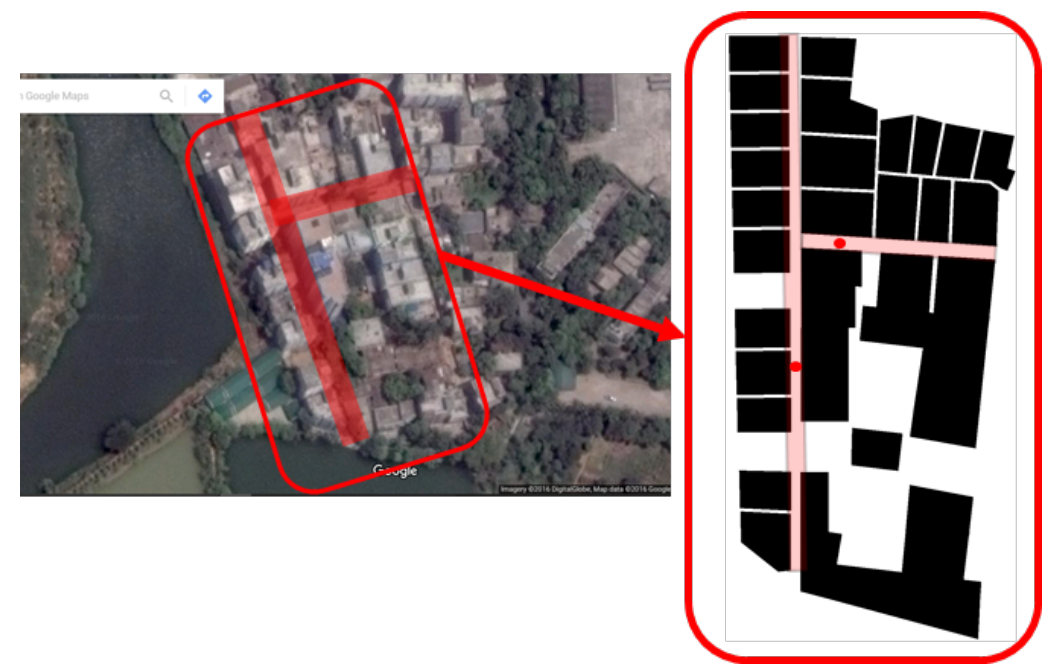

a. TRA1EW and TRA1NS

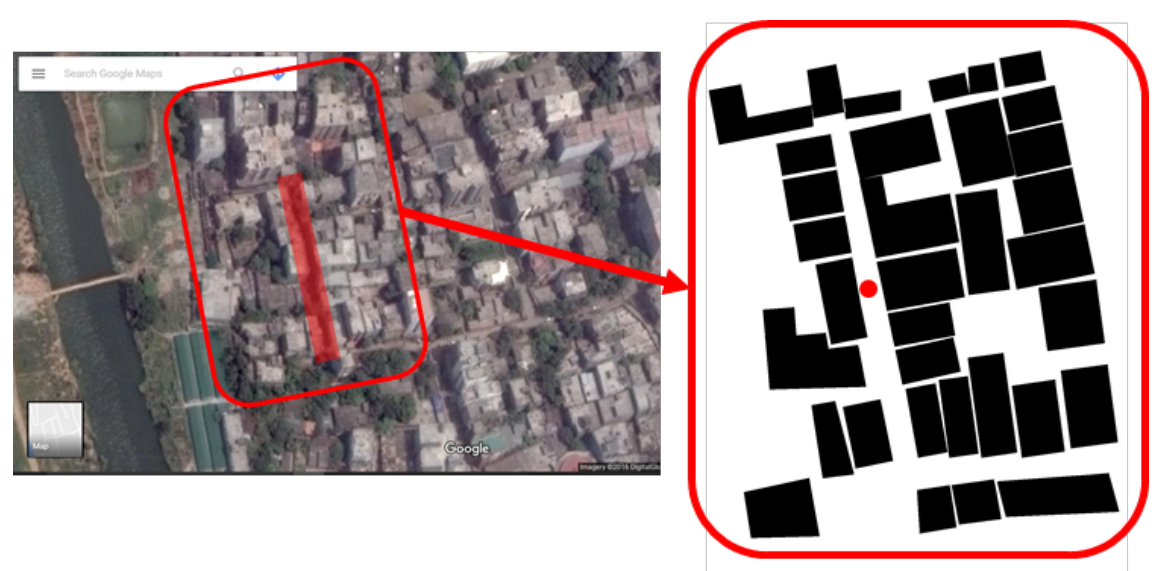

b. TRA2NS 


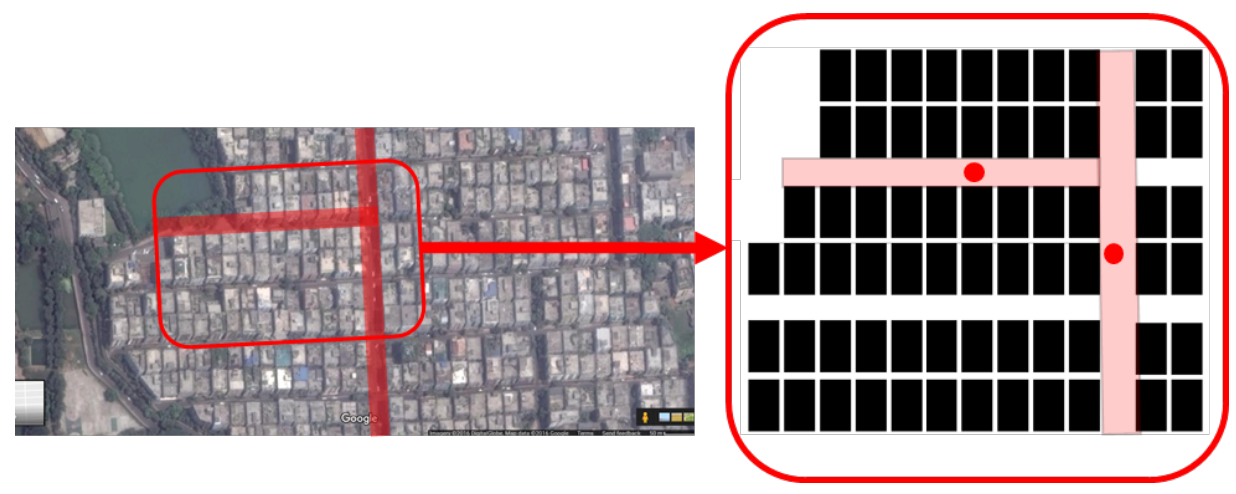

c. FRA2EW and FRA2NS

Figure continues to the next page

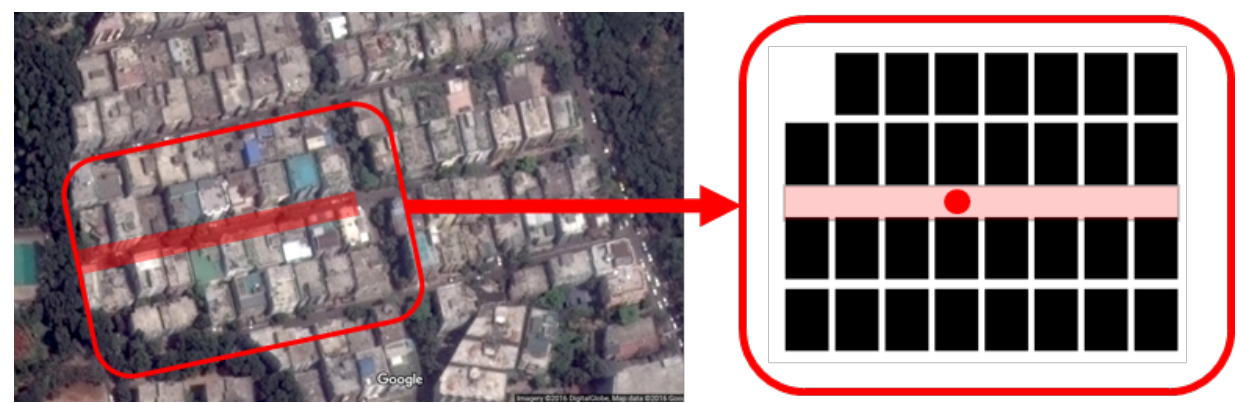

d. FRA1EW

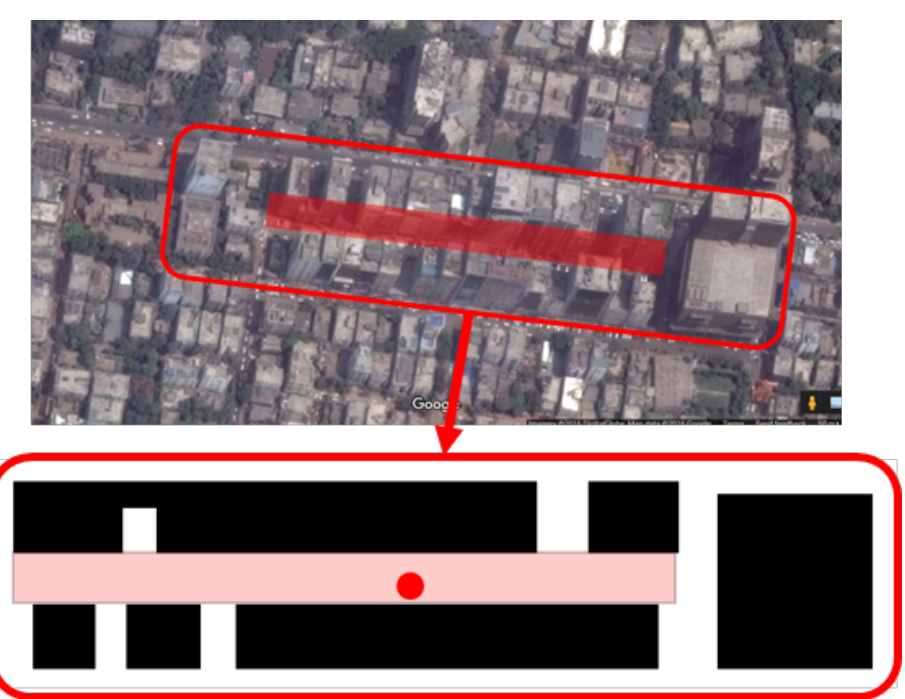

e. CAEW 

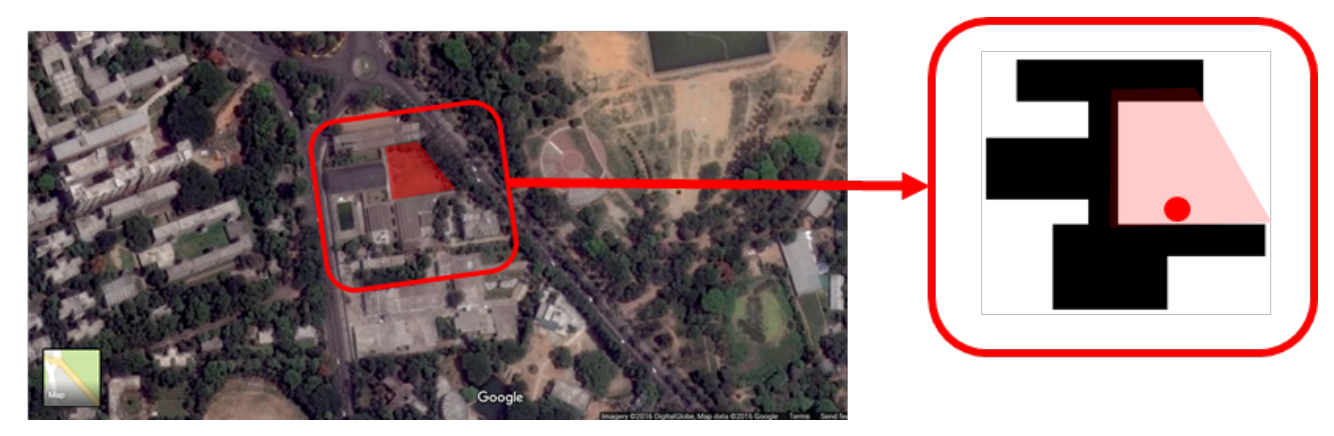

f.

ECA

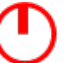

Measurement point

Figure 1. Location of the urban canyons in the case study sites and respective monitoring points. Map data @2015 Google Earth, Dhaka, Bangladesh. Source: "Dhaka".23 ${ }^{0} 46$ '02.75" N and 90 25 '10.32" E. Google Earth. January 07, 2015 (Google Earth V 7.1.4.1529., 2015).

Wind speed was measured with a three-cup anemometer at the same height (1.1 to $1.2 \mathrm{~m}$ ) recorded with an OM-CP-WIND101A data logger. Globe temperature was measured using a Tiny-tag data logger with a thermocouple thermistor probe. The globe thermometer consisted of a $40 \mathrm{~mm}$ ping-pong ball painted in matte grey and the thermistor probe inserted inside the ball, following the approach suggested by de Dear (1987) and Thorsson et al. (2007). Mean radiant temperature (Tmrt) was calculated from globe temperature using the equations in Thorsson et al. (2007). The range and accuracy of the instruments used in the study conforms to the ISO standards (ISO 7726, 1998)

Microclimatic monitoring was conducted in typical weather conditions in summer. In Dhaka, perfectly clear-sky conditions throughout the day are available only during the winter (cool-dry) period. Since, heat is a dominat problem in tropical cities like Dhaka, this study specifically looked into pedestrian comfort situation during the hot/ warm months and no survey/ monitoring was carried out in winter. During the survey period in autumn 2014, the sky was mostly overcast during the morning with brief clear spells. Afternoons were generally bright and sunny with high cloud coverage, usually 5 octas, whereas late afternoons $(3: 00-5: 00 \mathrm{pm})$ were milder with less direct sun. In summer 2015, mornings were overcast with more frequent clear spells. Late afternoons had a stronger solar radiation gradually transforming into a milder sun in the early evenings $(5: 00-6: 00 \mathrm{pm})$ with a more comfortable ambience than the afternoons.

Air temperature, relative humidity and globe temperature were measured at a 5minute frequency during autumn 2014. They were measured at a 1-minute frequency during summer 2015 but later converted to 5-minute frequency for easy comparison. Vapour pressure is calculated using the RayMan (Matzarakis, Rutz and Mayer, 2010) software. Wind speed is measured at a 1-minute frequency and also converted to a 5-minute frequency. For air temperature and relative humidity, globe temperature and wind speed the number of 
readings collected from the microclimatic sites were 3686, 2886 and 5440 (1-minute frequency). Altogether, 7660 readings (5-minute frequency) were used in this study.
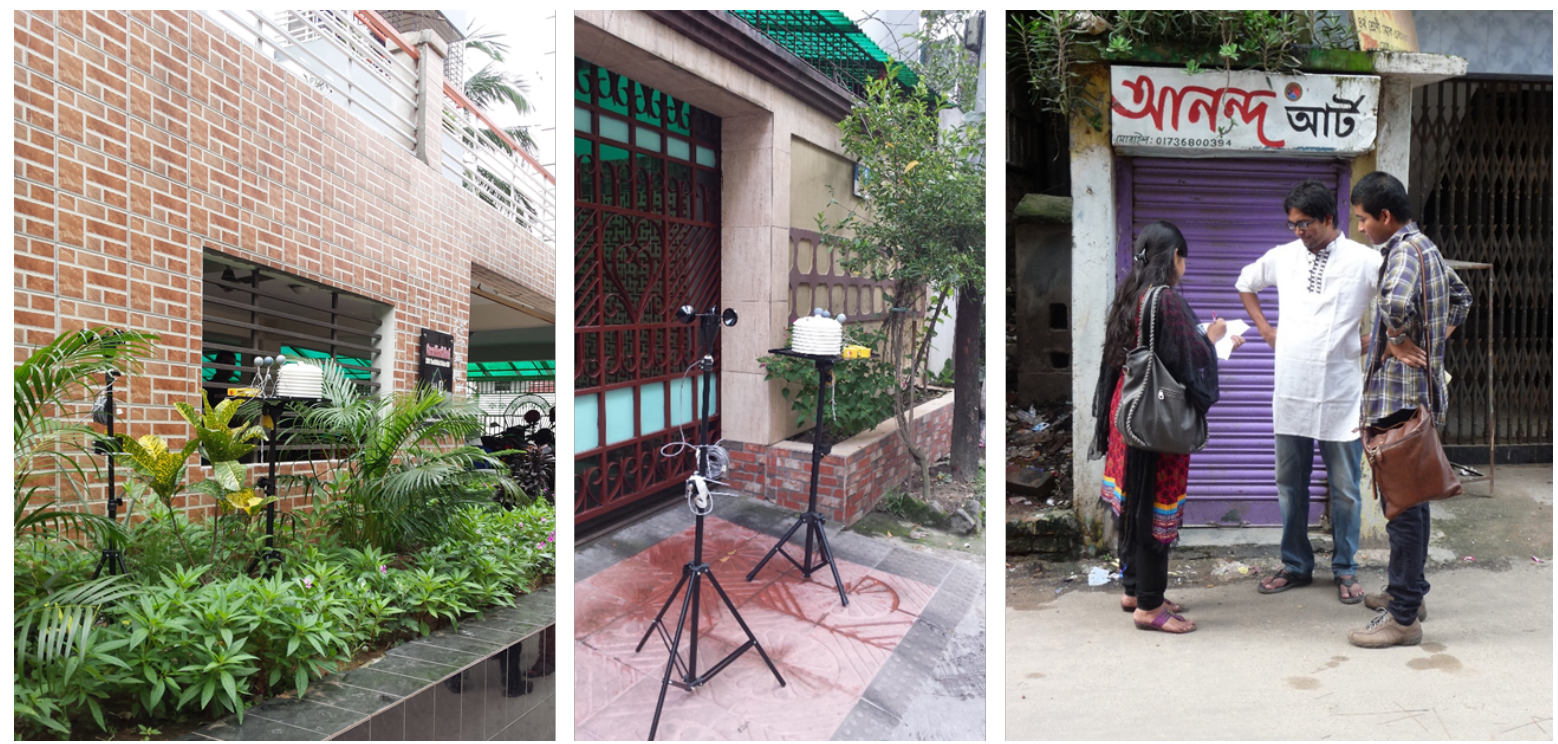

Figure 2. Microclimatic measurement in street canyons and simultaneous questionnaire survey

\subsection{Urban geometry parameters}

The most important parameters to describe the geometry or physical form of urban canyons include $\mathrm{H} / \mathrm{W}$ ratio (aspect ratio) and SVF. H/W ratio, commonly referred to as the aspect ratio (Figure 1), is a key urban geometry parameter affecting the incoming and outgoing solar radiation, radiation flux and wind flow in an urban canyon (Xi et al., 2012). On the other hand, SVF has been defined by Oke (1987) as the ratio of the amount of sky visible from a given point on the ground to the potentially available sky hemisphere subtended by a horizontal surface. SVF is an important parameter to measure Urban Heat Island (UHI) impact (Kikegawa et al., 2006) which is dimensionless and ranges from 0 to 1. Studies have shown that lower SVF is associated with lower daytime air temperature by creating a cool island effect. This phenomenon is similar to the decreasing air temperature with increasing $\mathrm{H} / \mathrm{W}$ ratio.

The study has used two parameters regarding $\mathrm{H} / \mathrm{W}$ ratio: firstly, $\mathrm{H} / \mathrm{W}$ ratio of the actual point where microclimatic measurement was carried out during the field survey $(\mathrm{H} / \mathrm{W}$ ratio_MP) and the standard deviation of $\mathrm{H} / \mathrm{W}$ ratio $(\mathrm{H} / \mathrm{W}$ ratio_STDEV) in the street canyon. Likewise, two types of SVF values are used in this study: SVF of the actual point where the microclimatic measurement was carried out during the field survey (SVF_MP) and the standard deviation of SVF (SVF_STDEV) values in the street canyon. 


\subsection{Questionnaire survey}

A questionnaire survey was carried out along with physical measurements to understand the impact of urban geometry and thereby, urban microclimate on pedestrian comfort. The survey includes 1302 interviews conducted across the case-study areas. Out of 1302 respondents, 16 responses were excluded due to missing values. This corresponds to a final data set of 1286 responses. The questionnaire can be found in (Sharmin, Steemers and Matzarakis, 2015).

The questionnaire was prepared on the basis of previous research $(\mathrm{Ng}$ and Cheng, 2012; Yang, Wong and Jusuf, 2013) and a pilot survey conducted in August 2012. For proper execution of the survey, the questionnaire was translated into the local language, Bengali, and was designed in a simple and concise manner aiming to complete each survey within 5 minutes.

The pedestrians near the measurement sites were randomly invited to answer the questionnaire. They were asked about their thermal sensation, acceptability and preferences along with humidity, wind speed and solar radiation sensations. Physical attributes like age, gender, body type and activity were noted. Clothing information was obtained from observation.

Interviewees were mainly asked to express their thermal sensation level based on ASHRAE 7-point scale (-3 cold; -2 cool; -1 slightly cool; 0 neutral; +1 slightly warm; +2 warm; +3 hot). Their thermal preference was noted on a 3-point McIntyre Scale (Prefer warmer, prefer no change, prefer cooler) (McIntyre, 1980). Thermal acceptability was assessed by asking whether the thermal environment was acceptable or unacceptable. Humidity, wind speed and solar radiation sensations were recorded on individual 5-point scales (Ng and Cheng, 2012).

\subsection{PET analysis}

Analysing the responses from the thermal comfort survey, this study intends to develop a summer PET scale (Physiologically Equivalent Temperature) for the tropical context of Dhaka city. PET (Höppe, 1999) is a widely used thermal comfort index based on the Munich Energy-balance Model for Individuals (MEMI). It is defined as the air temperature at which, in a typical indoor setting $(\mathrm{Ta}=\mathrm{Tmrt}$, water vapor pressure $=12 \mathrm{hPa}, \mathrm{v}$ $=0.1 \mathrm{~m} / \mathrm{s}$ ), the human energy budget for the assumed indoor conditions is balanced by the same skin temperature and sweat rate as under the actual complex outdoor conditions to be assessed (Lin, 2009). PET is easily comprehensible by urban planners and policy makers, who may be unfamiliar with the human biometeorological terminology, as it is denoted by Degree Celsius $\left({ }^{0} \mathrm{C}\right)$. There are many other models which have been frequently used in outdoor thermal studies, such as PMV (Predicted Mean Vote) (Fanger, 1970), OUT_SET (Out_Standard Effective Temperature) (Pickup and de Dear, 2000; Spagnolo and de Dear, 2003), and UTCI (Universal Thermal Climate Index) (http://www.utci.org/). However, the study does not intend to produce a comparative analysis between different indices. Therefore, 
the PET index, which is already an established tool in current research (Lin and Matzarakis, 2008; Lin, Matzarakis and Hwang, 2010) for predicting outdoor thermal conditions, has been adopted in this study.

It is imperative to define the PET ranges in which pedestrians are comfortable before applying this to a particular climatic context. PET ranges have been developed mainly for western and middle European countries which motivated researchers to make adjustments for different climatic zones. A review of 110 studies by (Potchter et al., 2018) suggested the PET neutral sensation for hot climate ranges between $17{ }^{\circ} \mathrm{C}$ to $33{ }^{\circ} \mathrm{C}$ and for cold climate ranges between $6{ }^{\circ} \mathrm{C}$ to $28{ }^{\circ} \mathrm{C}$. For example, the neutral PET range for hot-humid climate in Dar es Salaam, Tanzania is $23-31^{\circ} \mathrm{C}$ (Ndetto and Matzarakis, 2017); for hot-arid climate in Cairo, Egypt is $24.3-29.5^{\circ} \mathrm{C}$ (Elnabawi, Hamza and Dudek, 2016); for Mediterranean climate in Crete, Greece is $20-25^{\circ} \mathrm{C}$ (Tsitoura, Tsoutsos and Daras, 2014) and for temperate climate in Glasgow, UK is $9-18^{0} \mathrm{C}$ (Krüger et al., 2013).

In the hot and humid subtropical context of Taiwan, Lin \& Matzarakis (2008) has done an extensive study to define PET ranges (Table 3) by applying the analysis of de Dear $\&$ Fountain (1994). Their methodology has two stages: the first stage involves calculating the Mean Thermal Sensation Vote (MTSV) for each $1^{\circ} \mathrm{C}$ interval for the concerned thermal comfort index, while the second stage involves defining the "thermal acceptable range" of MTSV. The methodology was applied in several recent research for modifying the scales of various indices in different climatic zones. For example, Elnabawi, Hamza and Dudek, 2016; Hirashima, Assis and Nikolopoulou, 2016; Pantavou, Lykoudis and Nikolopoulos, 2016; Johansson et al., 2018; Li, Zhang and Zhao (2016) etc. According to Potchter et al. (2018), a total of 22 studies have modified the PET neutral range for various contexts using the methodology of Lin and Matzarakis (2008). Due to the established confidence, this study has also modified the PET ranges to apply to the case-study settings following the method in Lin \& Matzarakis (2008).

Table 3. Thermal sensations and PET classes for Taiwan and Western/ Middle European classes (Lin \& Matzarakis, 2008)

\begin{tabular}{lll}
\hline Thermal sensation & $\begin{array}{l}\text { PET range for Taiwan }\left({ }^{\mathbf{0}} \mathbf{C}\right. \\
\text { PET) }\end{array}$ & $\begin{array}{l}\text { PET range for Western/ Middle } \\
\text { European cities ( }{ }^{\mathbf{0}} \mathbf{C} \text { PET) }\end{array}$ \\
\hline Very cold & $<14$ & $<4$ \\
Cold & $14-18$ & $4-8$ \\
Cool & $18-22$ & $8-13$ \\
Slightly cool & $22-26$ & $13-18$ \\
Neutral & $26-30$ & $18-23$ \\
Slightly warm & $30-34$ & $23-29$ \\
Warm & $34-38$ & $29-35$ \\
Hot & $38-42$ & $35-41$ \\
Very hot & $>42$ & $>41$ \\
\hline
\end{tabular}

Meteorological measurements of ambient air temperature, mean radiant temperature (calculated from globe temperature), relative humidity and wind speed carried out during the questionnaire survey along with clothing and activity information of the respondents were 
used to calculate the PET using RayMan. Three-dimensional models were built using 'obstacles' and 'sky view factor' (using the fish-eye image of the case-study area) information in RayMan. Average wind speed conditions during the survey period in the case study areas were considered for calculating PET. The reason for this is, the fluctuation recorded by the anemometer was not reflected in the pedestrians' responses while collecting their comfort sensations (TSV) and initial PET values were found lower than actual responses. The anemometer (OM-CP-WIND101A-KIT Series) employed in this study is more appropriate for meteorological stations and high wind speeds, and not as ideal for low level wind speeds in urban streets, or areas with turbulence. To deal with this deficiency, average wind conditions (measured average) are assumed while calculating the PET.

\section{Results and discussion}

\subsection{Correlation between urban geometry parameters and climatic variables}

A correlation analysis was performed to understand the impact of urban geometry parameters upon climatic variables. Correlations obtained between urban geometry and microclimate variables were for the times of the surveys between 9:00-18:00. Results can be found on Table 5. The analysis included only residential cases and excluded commercial and educational areas (CAEW, ECA) due to different land use pattern as well as different geometry of the urban areas. As can be seen from Figure 1, commercial and educational areas are characterised with a very different geometry in comparison to the residential areas.

Concerning the residential areas only, a moderate correlation is found between air temperature (Ta) and geometry parameters, suggesting that for deeper urban canyons (with higher $\mathrm{H} / \mathrm{W}$ ratios) Ta will reduce. Furthermore, the standard deviations of $\mathrm{H} / \mathrm{W}$ ratio $(\mathrm{H} / \mathrm{W}$ Ratio_STDEV) show higher correlations, signifying that greater variation in $\mathrm{H} / \mathrm{W}$ ratio will have a negative impact on Ta. On the other hand, vapour pressure will reduce in a deeper canyon and in a canyon with higher standard deviations of $\mathrm{H} / \mathrm{W}$ ratio and SVF.

With regards to Tmrt and GT, strong or moderately strong negative correlations are found with $\mathrm{H} / \mathrm{W}$ ratio and positive correlations are found with SVF. This suggests that GT and Tmrt will reduce in a deep or narrow street canyon and in a compact area. Standard deviations of the H/W ratio (H/W Ratio_STDEV) show strong correlations with Tmrt and GT $(\mathrm{r}=-0.480$ and $\mathrm{r}=-0.499$ respectively). Correlations reported from other studies concerning Tmrt and SVF show $\mathrm{R}^{2}$ values between 0.318 and 0.609 (Tan et al. 2014).

In terms of wind speed, very strong to moderately strong correlations are found showing that wind speed will increase in deeper and variable canyons. A similar phenomenon is noticed during the field measurements, deeper canyons with greater variability in building heights were found to have greater turbulence and funnelling effects and, as a result, higher wind speed. Standard deviations of both $\mathrm{H} / \mathrm{W}$ ratio and SVF also present very strong correlations. Differences in the heights of neighbouring buildings have been identified as an important factor from the urban ventilation aspect. Even though buildings may diminish the speed of the regional winds near ground level, individual buildings exceeding those around them in height create strong wind currents in the area (Givoni, 1998). 
Table 4. Summary of the physical data of outdoor microclimate during survey days between 9:00-18:00

\begin{tabular}{lllll}
\hline & Mean & Max & Min & SD \\
Air temperature, ${ }^{0} \mathrm{C}$ & 32.3 & 37.0 & 27.6 & 2.0 \\
Globe temperature, ${ }^{0} \mathrm{C}$ & 33.4 & 40.9 & 27.7 & 2.7 \\
Relative humidity, $\%$ & 70.4 & 84.8 & 48.3 & 7.8 \\
Vapour pressure, $\mathrm{hPa}$ & 33.7 & 37.2 & 23.7 & 2.2 \\
Wind speed, $\mathrm{m} / \mathrm{s}$ & 0.8 & 10.9 & 0.0 & 1.6 \\
Mean radiant temperature, ${ }^{0} \mathrm{C}$ & 33.6 & 41.9 & 27.4 & 2.9 \\
\hline
\end{tabular}

Table 5. Correlation between urban geometry parameters and climatic parameters

\begin{tabular}{|c|c|c|}
\hline Microclimate parameter & Urban geometry parameter & Correlation \\
\hline \multicolumn{3}{|l|}{ Air_temperature } \\
\hline & H/W Ratio_MP & -0.135 \\
\hline & H/W Ratio_STDEV & -0.241 \\
\hline & SVF_MP & 0.135 \\
\hline \multicolumn{3}{|l|}{ Vapour pressure } \\
\hline & H/W Ratio_MP & -0.448 \\
\hline & H/W Ratio_STDEV & -0.299 \\
\hline & SVF_MP & 0.197 \\
\hline & SVF_STDEV & -0.329 \\
\hline \multicolumn{3}{|l|}{ Mean radiant temperature } \\
\hline & H/W Ratio_MP & -0.246 \\
\hline & H/W Ratio_STDEV & -0.480 \\
\hline & SVF_MP & 0.399 \\
\hline \multicolumn{3}{|l|}{ Globe temperature } \\
\hline & H/W Ratio_MP & -0.285 \\
\hline & H/W Ratio_STDEV & -0.499 \\
\hline & SVF_MP & 0.419 \\
\hline \multicolumn{3}{|l|}{ Wind speed } \\
\hline & H/W Ratio_MP & 0.721 \\
\hline & H/W Ratio_STDEV & 0.423 \\
\hline & SVF_MP & -0.422 \\
\hline & SVF_STDEV & 0.613 \\
\hline
\end{tabular}




\subsection{Questionnaire data}

The survey was conducted for 11 days, of which 6 days were in autumn 2014 and 5 days were in summer 2015. Table 6 shows the number and percentage of people interviewed at each site. Around $42 \%$ of the data was collected in autumn 2014 and the remaining 58\% during summer 2015. Each site was planned to be examined once in each season. However, due to weather uncertainties and political turmoil in Dhaka city, the sites TRA1NS and ECA could not be visited during summer 2015 .

Table 6. Number of respondents across different sites and seasons

\begin{tabular}{l|l|l|l|l|l|l|l|l}
\hline & TRA1EW & TRA1NS & TRA2NS & FRA1EW & FRA2EW & FRA2NS & CAEW & ECA \\
\hline $\begin{array}{l}\text { Autumn 2014 } \\
(\mathrm{n}=542), 42 \%\end{array}$ & 46 & 41 & 62 & 68 & 58 & 63 & 122 & 82 \\
\hline $\begin{array}{l}\text { Summer 2015 } \\
(\mathrm{n}=760), 58 \%\end{array}$ & 73 & 0 & 179 & 144 & 147 & 95 & 122 & 0 \\
\hline Total $(\mathrm{n}=1302)$ & 119 & 41 & 241 & 212 & 205 & 158 & 244 & 82 \\
\hline Percentage & $9 \%$ & $3 \%$ & $19 \%$ & $16 \%$ & $16 \%$ & $12 \%$ & $19 \%$ & $6 \%$ \\
\hline
\end{tabular}

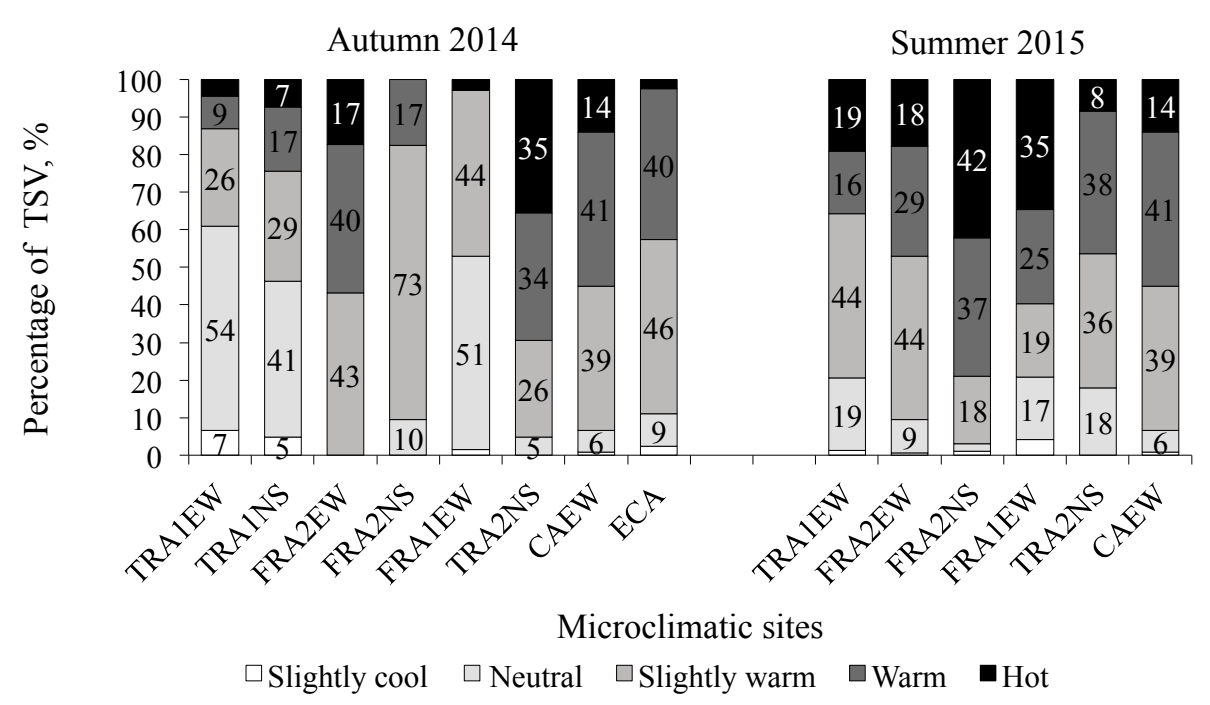

Figure 3. Percentage frequency for the TSV across different sites

The largest amount of data (19\% each) were collected in CAEW and TRA2NS. The first one being a commercial area and home to three universities, the number of pedestrians was remarkably high. The second site, which is a traditional area with residential as well as commercial activities, also showed high pedestrian occurrences. This is due to the commercial activity and the connectivity of the street itself to other neighbouring areas. The formal residential areas, FRA1EW, FRA2EW and FRA2NS, although predominantly residential neighbourhoods, also contained small and medium scale businesses. Most of these are garment buying houses (mediator agencies between the retailers and clothing manufacturers) for the garment industry. This has generated high pedestrian movement in the area. The pedestrians are typically employees in the offices as well as the residents in the 
neighbourhood. Traditional residential areas TRA1EW and TRA1NS, on the other hand, are located at the edge of the respective neighbourhoods. The areas have similar commercial activities as TRA2NS. The pedestrians visible in these streets are mainly the residents of the area. The percentage of people in the educational area ECA is also less (6\%). This is because the population is mainly students who gather here for academic or recreational purposes.

Looking at the individual case-study areas in Figure 3, a variety of thermal sensations across the sites can be found. Over $70 \%$ people in the sites TRA1EW, TRA1NS, FRA2NS and FRA1EW (in autumn 2014) felt between 'neutral' or 'slightly warm'. Individual sites that show a similar preponderance (in summer 2015) are TRA1EW, FRA2EW and TRA2NS with over $50 \%$ people between 'neutral' or 'slightly warm'. On the other hand, in sites TRA2NS and CAEW during autumn 2014 and FRA2NS, FRA1EW, TRA2NS and CAEW during summer 2015, the results incline predominantly towards 'warm' or 'hot' sensations. These sites are characterised by similar building heights and plot sizes with a lack in diversity of urban form in spite of being compact.

\subsection{Thermal comfort and urban microclimate}

\subsubsection{Correlation analysis of TSV and meteorological variables}

During the questionnaire survey, air temperature ranged between $27.6-37.0^{\circ} \mathrm{C}$, relative humidity between 48 - 85\%, vapour pressure between 23.7 - $37.2 \mathrm{hPa}$, globe temperature between $27.7-40.9^{\circ} \mathrm{C}$ and Tmrt between $27.4-41.8^{0} \mathrm{C}$ (Table 4). Wind speed remained generally low (mean $=0.8 \mathrm{~m} / \mathrm{s}$ ). However, higher wind speed along with some gusts was visible in the traditional areas with greater building height variation and in the commercial area with high-rise structures, especially where the funnelling effect was created. According to the data collected from Bangladesh Meteorological Department at Dhaka, the survey days can be regarded as typical days when the high temperature is coupled with high humidity, having high cloud coverage (average cloud coverage 5.5 oktas).

The physical configuration of the urban canyons affects its microclimate (Nikolopoulou, Baker and Steemers, 2001; Santamouris et al., 2001). There are other important factors, such as building materials and their albedo effect, however urban geometry plays a more crucial role (Andreou, 2013). Therefore, this study seeks to evaluate the impact of urban geometry on thermal sensation by examining the correlation between climatic variables and actual thermal sensation responses collected through the questionnaire survey. A linear regression analysis is carried out to understand their association (Table 7). Each meteorological parameter is separately examined against thermal sensation vote (TSV). Linear regression outcome shows that air temperature, vapour pressure, globe temperature and Tmrt were statistically significant with TSV. Wind speed is statistically insignificant and therefore the square root of wind speed is chosen instead. Individual linear regression output between TSV and meteorological and important personal parameters is listed in Table 7.

A multiple regression model is produced to predict TSV using air temperature, vapour pressure, Tmrt and Windspeedsqrt (square root of wind speed) (Equation 1). The relative 
humidity and globe temperature are excluded from the multiple regression model due to the problem of multicollinearity. These are highly correlated with air temperature with Pearson's $\mathrm{r}$ coefficient of $-0.83,0.83$ respectively. Tmrt, also strongly correlated with air temperature ( $\mathrm{r}$ $=0.81$ ), is still included in the model since its inclusion resulted in better prediction by the model. There are several precedence studies in the literature where correlated co-variables were incorporated in the multiple regression analysis while determining the TSV. For example, Nikolopoulou, Lykoudis and Kikira (2003) included air temperature, globe temperature, wind speed and relative humidity in a multiple regression model to determine TSV. Similarly, Pantavou \& Lykoudis (2014) used air temperature, relative humidity and wind speed along with solar radiation and atmospheric pressure in the linear model. Therefore, in this study, the thermal sensation linear meteorological model includes air temperature, Tmrt, vapour pressure and Windspeedsqrt:

$$
\begin{gathered}
\text { TSV_predicted linear meteorological model }=-5.060+0.164 * \text { Ta }+ \\
0.068 * \text { Tmrt }-0.027 * \text { Vapour pressure }-0.138^{*} \text { Windspeedsqrt } \\
\left(R^{2}=0.236\right)
\end{gathered}
$$

In Equation (1), $\mathrm{R}^{2}$ is 0.236 , which means that meteorological variables explain nearly $24 \%$ of the comfort sensation of pedestrians. The F-statistics is 96.1, which is large and significant, so the model has improved in predicting outcome over the mean model (simple statistical forecasting model that uses the mean of the sample data). $F$ is significant at $\mathrm{p}<0.000$, so we can say that the regression model is significant.

Different correlation coefficients, such as Pearson's $r$ (for normally distributed data), Spearman's $\rho$ (for skewed data) are applied to see the association between climatic variables and TSV, an ordered variable (Table 7). Pearson's correlation is mainly implemented between two continuous variables when both variables are individually normally distributed. The Spearman rank order correlation coefficient was also examined since it is suitable for the ordinal variable. Spearman's $\rho$ (rho) is a non-parametric measure of the strength and direction of association that exists between two variables which measure the correlation between the thermal response variables (Yang et al. 2013). TSV is found to increase towards hotter sensations with the increase of air temperature, globe temperature, Tmrt and vapour pressure. The correlation between these and TSV is moderately strong (Pearson's $r=0.47,0.45$ and 0.44 respectively), except for vapour pressure $(r=0.12)$ and statistically significant. Nikolopoulou \& Lykoudis (2006), for their study across different European countries revealed that TSV correlates better with globe temperature $(r=0.53)$ than air temperature $(\mathrm{r}=0.43)$, while this study finds air temperature to be the most important parameter. The correlation between wind speed and TSV is also weak and opposite (Spearman's $\rho=-0.149$ ). This means TSV reduces with the increase of wind speed, which is expected in a tropical climatic context. 
Table 7. Regression coefficients of simple linear regression between thermal sensation vote (TSV) and individual meteorological parameters

\begin{tabular}{|c|c|c|c|c|c|c|c|c|}
\hline$\frac{0}{\frac{0}{0}}$ & ن⿺辶 & & 总 & 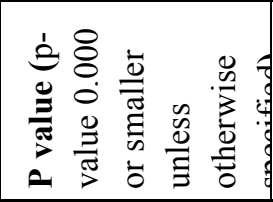 & 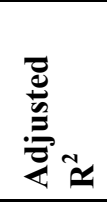 & 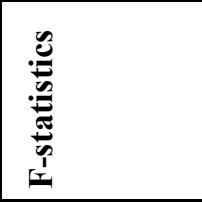 & 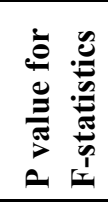 & 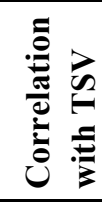 \\
\hline \multirow{2}{*}{$\begin{array}{l}\text { TSV } \sim \text { Air } \\
\text { temperature }\end{array}$} & Intercept & -6.146 & 0.412 & 0.000 & \multirow[t]{2}{*}{0.221} & \multirow{2}{*}{$\begin{array}{l}349.3 \text { on } 1 \\
\text { and } 1229 \mathrm{DF}\end{array}$} & \multirow[t]{2}{*}{0.000} & \multirow[t]{2}{*}{0.470} \\
\hline & $\begin{array}{l}\text { Regression } \\
\text { Coefficient }\end{array}$ & 0.238 & 0.013 & 0.000 & & & & \\
\hline \multirow{2}{*}{$\begin{array}{l}\text { TSV } \\
\text { Vapour } \\
\text { pressure }\end{array}$} & Intercept & -0.300 & 0.450 & 0.505 & \multirow[t]{2}{*}{0.013} & \multirow{2}{*}{$\begin{array}{l}16.92 \text { on } 1 \\
\text { and } 1229 \mathrm{DF}\end{array}$} & \multirow[t]{2}{*}{0.000} & \multirow[t]{2}{*}{0.117} \\
\hline & $\begin{array}{l}\text { Regression } \\
\text { Coefficient }\end{array}$ & -0.055 & 0.013 & 0.000 & & & & \\
\hline \multirow{2}{*}{$\begin{array}{l}\text { TSV } ~ \\
\text { Globe } \\
\text { temperature }\end{array}$} & Intercept & -4.155 & 0.321 & 0.000 & \multirow[t]{2}{*}{0.204} & \multirow{2}{*}{$\begin{array}{l}316.3 \text { on } 1 \\
\text { and } 1229 \mathrm{DF}\end{array}$} & \multirow[t]{2}{*}{0.000} & \multirow[t]{2}{*}{0.452} \\
\hline & $\begin{array}{l}\text { Regression } \\
\text { Coefficient }\end{array}$ & 0.170 & 0.010 & 0.000 & & & & \\
\hline \multirow[t]{2}{*}{$\mathrm{TSV} \sim \mathrm{Tmrt}$} & Intercept & -3.749 & 0.306 & 0.000 & \multirow[t]{2}{*}{0.196} & \multirow{2}{*}{$\begin{array}{l}301.6 \text { on } 1 \\
\text { and } 1229 \mathrm{DF}\end{array}$} & \multirow[t]{2}{*}{0.000} & \multirow[t]{2}{*}{0.443} \\
\hline & $\begin{array}{l}\text { Regression } \\
\text { Coefficient }\end{array}$ & 0.158 & 0.009 & 0.000 & & & & \\
\hline \multirow{2}{*}{$\begin{array}{l}\text { TSV } \sim \text { Wind } \\
\text { speed }\end{array}$} & Intercept & 1.550 & 0.033 & 0.000 & \multirow[t]{2}{*}{-0.001} & \multirow{2}{*}{$\begin{array}{l}0.06745 \text { on } 1 \\
\text { and } 1229 \mathrm{DF}\end{array}$} & \multirow[t]{2}{*}{0.795} & \multirow[t]{2}{*}{-0.149} \\
\hline & $\begin{array}{l}\text { Regression } \\
\text { Coefficient }\end{array}$ & -0.005 & 0.018 & 0.795 & & & & \\
\hline \multirow{2}{*}{$\begin{array}{l}\text { TSV } \\
\text { SQRT Wind } \\
\text { speed }\end{array}$} & Intercept & 1.625 & 0.040 & 0.000 & \multirow[t]{2}{*}{0.005} & \multirow{2}{*}{$\begin{array}{l}7.623 \text { on } 1 \\
\text { and } 1229 \mathrm{DF}\end{array}$} & \multirow[t]{2}{*}{0.006} & \multirow[t]{2}{*}{-0.149} \\
\hline & $\begin{array}{l}\text { Regression } \\
\text { Coefficient }\end{array}$ & -0.122 & 0.044 & 0.006 & & & & \\
\hline
\end{tabular}

\section{Prediction of TSV using PET thermal comfort index and air temperature}

The calculation of PET is an objective measure of thermal comfort based mainly on the effect of climate on the thermal state of the body, independent of individual human behaviour (Cheng et al., 2012). It is therefore important to examine its relationship with the subjective thermal sensation collected during the questionnaire survey. Considering heat as the dominant problem in the tropical city Dhaka, the questionnaire survey mainly focusses in hot and warm periods. Figure 4(a) and Equation 2 shows the correlations between the actual thermal sensation vote (TSV) and PET. Since there was no response in 'Cool' (-2) and 'Cold' $(-3)$ categories, these are not presented in the figure.

Considering the fact that the correlations between the TSV and PET are not much higher compared to the correlations between the TSV and air temperature, the study also attempts to express the results in terms of air temperature besides PET. Expression of results in terms of air temperature has the advantage of simplicity as meteorological data sets always include it, while PET may not be available. The scatter plot between TSV and Air temperature and the associated regression equation is presented in Figure 4(b) and Equation 3. From the equations 2 and 3, the neutral PET and neutral air temperature can be determined to be $24.6^{\circ} \mathrm{C}$ and $25.8^{\circ} \mathrm{C}$, respectively. 


$$
\begin{gathered}
\text { TSV }=0.179 * \text { PET }-4.410, \\
R^{2}=0.234 \\
T S V=0.238^{*} \text { Air-temperature }-6.146, \\
R^{2}=0.221
\end{gathered}
$$

Thermal sensation vote (TSV) recorded for each respondent was further simplified by taking the mean TSV (MTSV) for every $1.0^{\circ} \mathrm{C}$ PET bin. The method applied by (Brager and Dear, 1998) is helpful in reducing disagreement between thermal sensation votes of respondents even when they are in the same environment. The method is useful because it makes the trend in the data obvious (Humphreys, Nicol and Susan, 2015). The reason for using $1.0^{\circ} \mathrm{C}$ interval is to define the "thermal acceptable range" for the PET index for the concerned climate. PET was divided into 17 data bins with $1.0^{\circ} \mathrm{C}$ interval and the mean thermal sensation vote (MTSV) was calculated for each bin. For example, the mean thermal sensation vote for 75 respondents is $1.15 \approx 1$, who are exposed to $30.0-31.0^{\circ} \mathrm{C}$ PET. Simple linear regression was performed on mean thermal sensation vote (MTSV) as a function of PET as shown in Figure 5. A stronger linear relationship was found between TSV and PET as also identified in previous studies (Lin, 2009; Salata et al., 2016):

$$
\begin{gathered}
M T S V=0.178 * P E T-4.375 \\
R^{2}=0.948
\end{gathered}
$$


a)

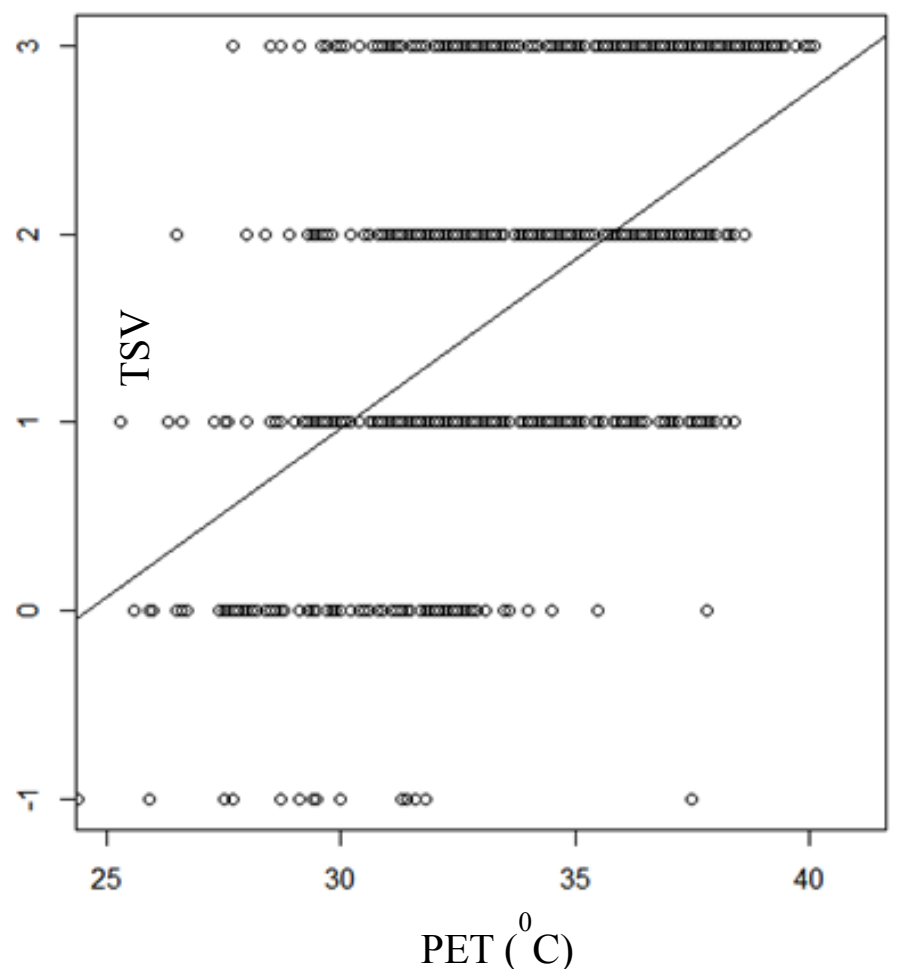

b)

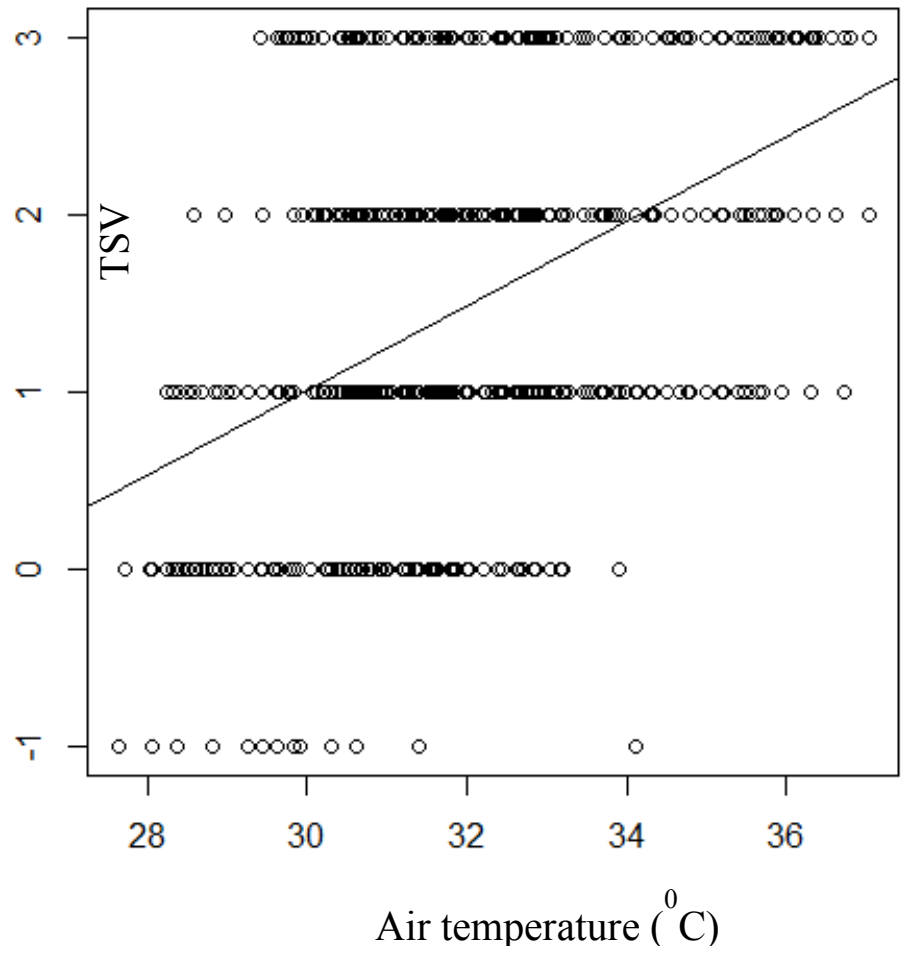

Figure 4. Scatter plot between a) TSV and PET, b) TSV and Air temperature 


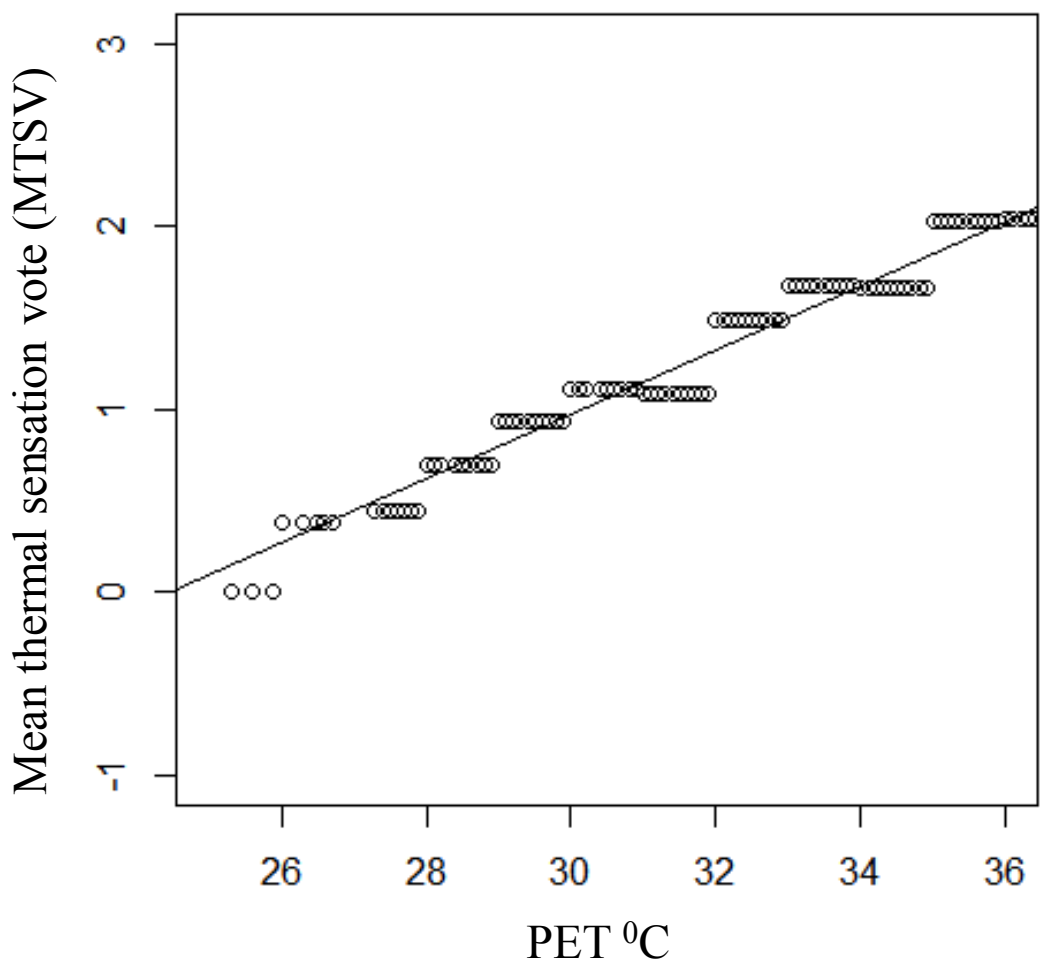

Figure 5. Regression of MTSV (Mean thermal sensation) and PET

Figure 6 shows the percentage of unacceptable votes against each $1.0^{\circ} \mathrm{C}$ interval of PET with a two-degree polynomial fitted curve superimposed onto the plot. In order to identify the summer comfort range, as suggested in Lin \& Matzarakis (2008), an 80\% acceptability limit was chosen. The threshold of the $80 \%$ acceptability limit is the intersections of the fitted curve and the $20 \%$ unacceptability line, which is around $26.9-$ $34.2^{0} \mathrm{C}$. In order to focus precisely on the comfort range and to minimize the data range, the $88 \%$ acceptability limits were chosen (Lin and Matzarakis, 2008) for "neutral" thermal sensation in order to determine the acceptable temperature range based on PET. The $88 \%$ acceptability limits are the intersections of the fitted curve and the $12 \%$ unacceptability line, which were $29.5-32.5^{\circ} \mathrm{C}$. Therefore, the acceptable PET (Yang, Wong and Zhang, 2013) range for Dhaka can be found between $29.5-32.5^{\circ} \mathrm{C}$. By applying the similar method, acceptable ranges for air temperature is found between $30.0-33.0^{\circ} \mathrm{C}$. 
a)

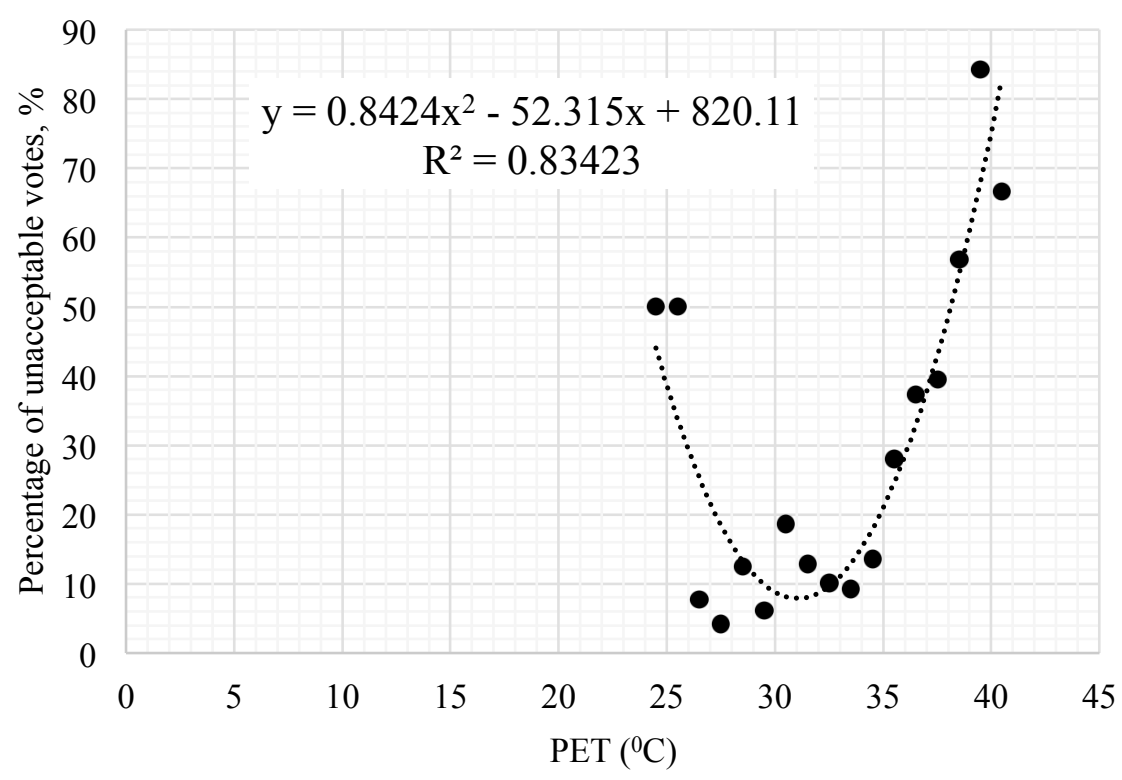

b)

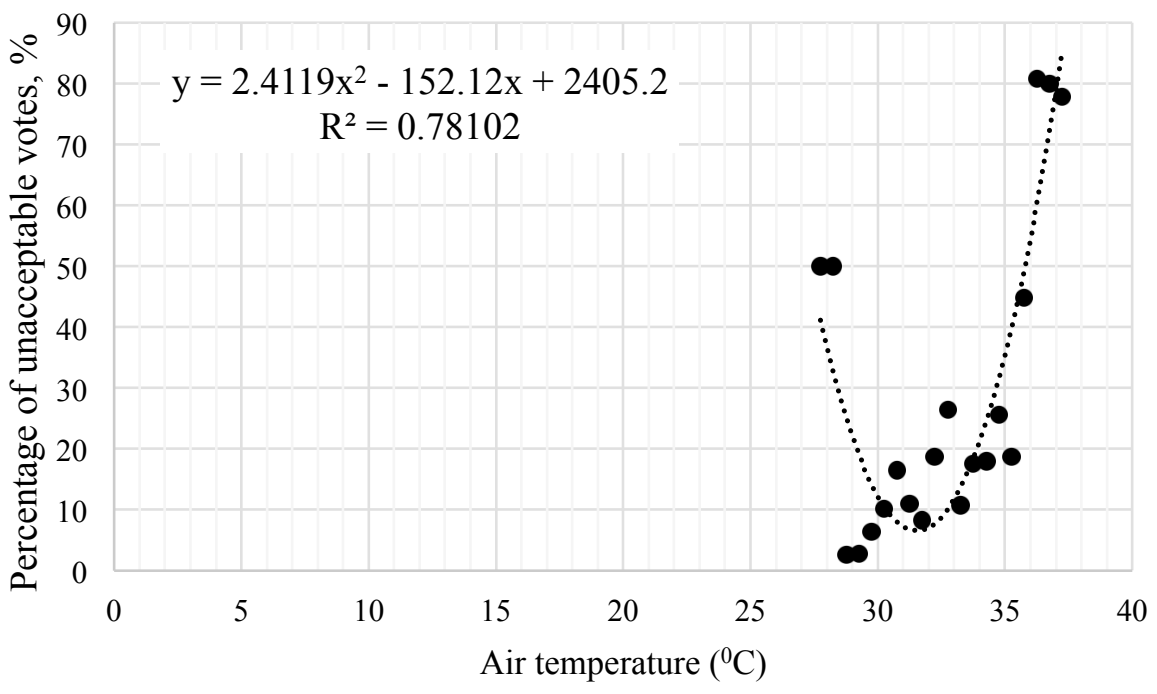

Figure 6. Percentage of unacceptable votes as a function of: a) PET, b) Airtemperature.

Following (Yang, Wong and Zhang, 2013), PET ranges of $29.5-32.5{ }^{\circ} \mathrm{C}$ were considered as the "Neutral" range. The other thermal sensation ranges in the scale feeling 'Slightly warm', 'Warm' and 'Hot' are determined by a $3.0^{\circ} \mathrm{C}$ increase of the 'Neutral' range in the line with the method used by Lin \& Matzarakis (2008). Likewise, "slightly cool" and "cool" are determined by a $3.0^{\circ} \mathrm{C}$ decrease of the "Neutral' range. The "cold" range could not be determined since there was no data below the "cool" range. The final summer PET and air temperature classification for Dhaka can be found in Table 8. 
Table 8. Summer PET classification for Dhaka

\begin{tabular}{l|l|l}
\hline Thermal sensation & $\begin{array}{l}\text { Acceptable PET range for } \\
\text { Dhaka }\left({ }^{\mathbf{O}} \mathbf{C} \text { PET) }\right.\end{array}$ & $\begin{array}{l}\text { Acceptable air- } \\
\text { temperature range for } \\
\text { Dhaka }\left({ }^{\mathbf{0}} \mathbf{C}\right)\end{array}$ \\
\hline Cool & $23.5-26.5$ & $24-27$ \\
\hline Slightly cool & $26.5-29.5$ & $27-30$ \\
\hline Neutral & $29.5-32.5$ & $30-33$ \\
\hline Slightly warm & $32.5-35.5$ & $33-36$ \\
\hline Warm & $35.5-38.5$ & $36-39$ \\
\hline Hot & $>38.5$ & $>39$ \\
\hline
\end{tabular}

By comparing the PET thermal scales, it shows that the acceptable neutral range of Dhaka $\left(29.5-32.5^{\circ} \mathrm{C}\right)$ is higher than that of Taiwan $\left(26-30^{\circ} \mathrm{C}\right)$ and also that of Western/Middle European $\left(18-23^{\circ} \mathrm{C}\right)$ scale (Table 2). The neutral acceptable range of Dhaka $\left(29.5-32.5^{\circ} \mathrm{C}\right)$ is also higher than the Neutral PET of $24.6^{\circ} \mathrm{C}$ found from Equation 2. Li, Zhang and Zhao (2016) have shown in their study that the most comfortable PETs in different seasons varied $3.0-4.0^{\circ} \mathrm{C}$ than the neutral temperatures. Likewise, in the summer context of Dhaka, neutral PET is found below the acceptable neutral ranges. This means, although the neutral PET itself could be quite narrow, the ranges people are actually able to accept could be much higher.

After calculating PET for each respondent, the calculated PET was classified according to the PET ranges mentioned in Table 5 and assigned a respective category (from 3 to +3 ) from the seven-point thermal sensation scale. The reason behind this was to calculate predicted TSV by applying the PET range (TSV Predicted_PET) as well the air temperature

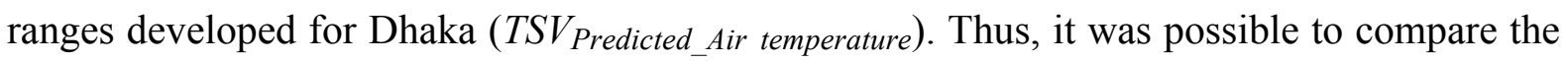
TSV predicted by PET ranges and TSV predicted by air temperature ranges with the actual TSV collected during the survey. Cross-tabulation (Figure 7a, b) of both predicted TSVs show the predictability of $T S V_{\text {Predicted_PET }}$ in the 'Slightly cool' 'Neutral', 'Slightly warm', 'Warm' and 'Hot' categories are 41.2\%, 62.1\%, 46.0\%, 23.7\% and 11.9\% respectively. On the other hand, the predictability of $T S V_{\text {Predicted_Air temperature }}$ in the above categories are $58.8 \%, 64.4 \%, 25.6 \%, 1.7 \%$ and $0 \%$ respectively. This shows, PET ranges for Dhaka can predict the actual TSVs in a better way compared to the air temperature ranges, especially for the warmer three categories. This implies that PET ranges are more suitable than air temperature ranges for the context of Dhaka for predicting TSV. 
a)

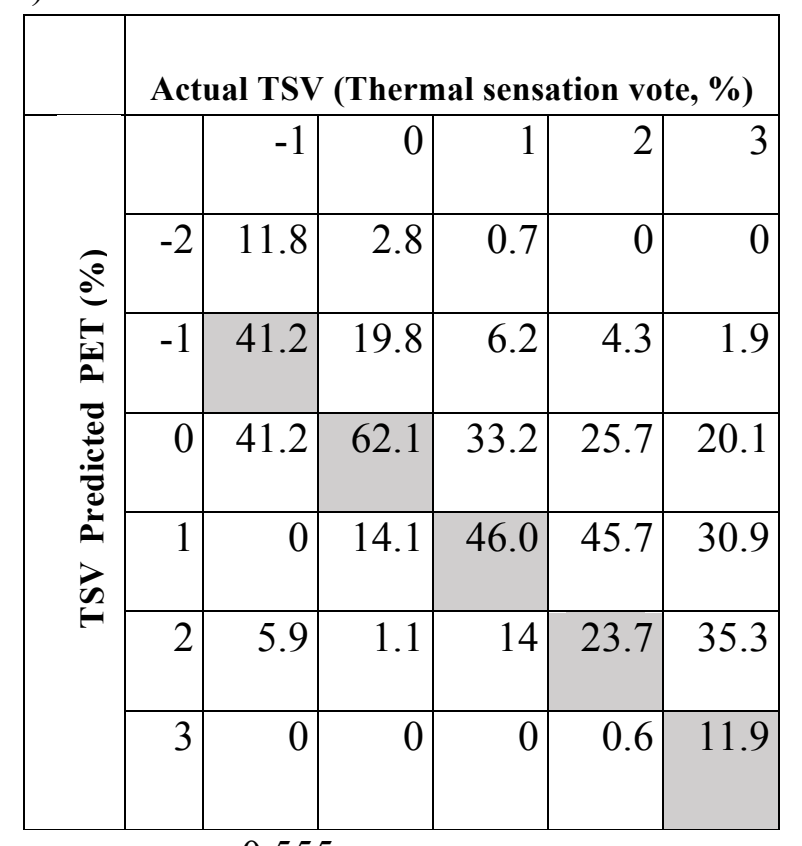

gamma

$: 0.555$

std. error : 0.027

CI $\quad: 0.5010 .608$ b)

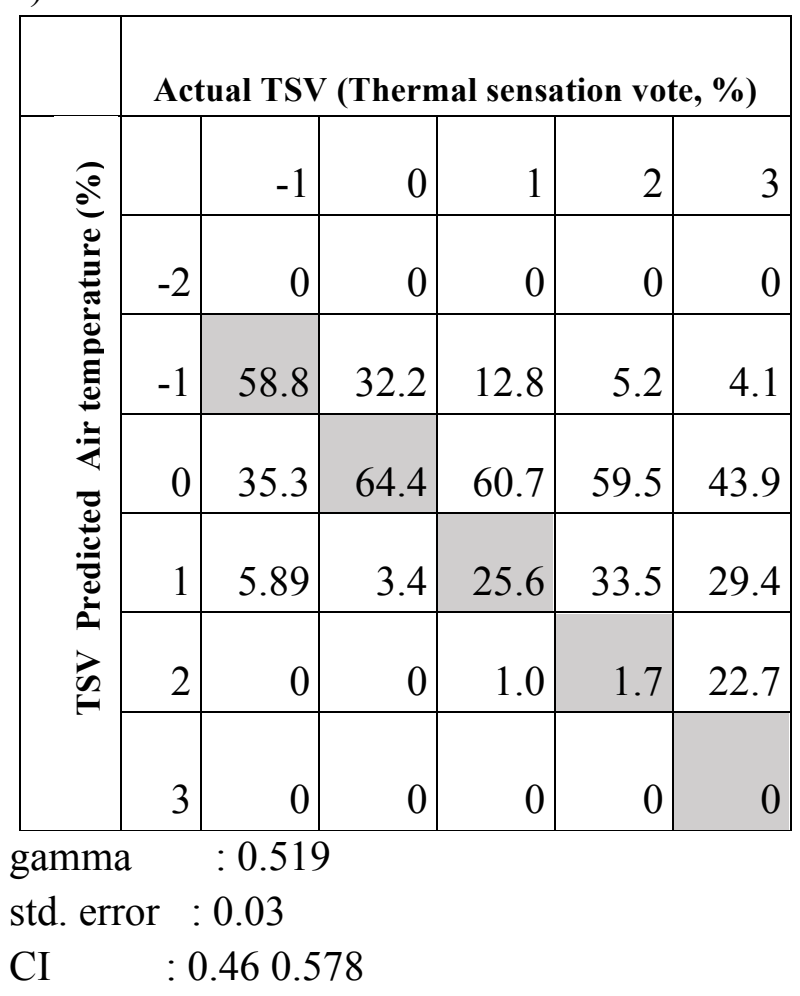

Figure 7. Cross-tabulation diagram of actual thermal sensation vote (TSV) by (a) TSV_Predicted_PET and (b)TSV_Predicted_Air temperature

\section{Conclusion}

Comfort surveys and objective field measurements were carried out in six different urban areas between summer and autumn for two years. The effect of urban geometry parameters $\mathrm{H} / \mathrm{W}$ ratio, SVF and their standard deviations across the urban canyon on microclimatic conditions was examined. The results reveal, greater variability in urban form as indicated by H/W Ratio_STDEV lowers the air temperature, globe temperature, mean radiant temperature and increases the wind speed within the urban canyon and thereby creates a favourable urban microclimate. Also, the association between people's subjective thermal comfort sensation and objective meteorological measurements indicates the degree of effect of microclimatic conditions on outdoor thermal comfort situations. Moderate to strong correlations were found between the TSV and climatic variables with air temperature, globe temperature and mean radiant temperature being the most important variables (correlation coefficients of $\mathrm{r}=0.47,0.45$ and 0.44 respectively) for the case study tropical climate.

Next, to understand the suitability of the existing thermal index in the concerned climate as well to assess the need for a prediction tool for assessing pedestrian thermal comfort, the PET index was applied. The subjective assessment in this study aided as a validation measure for the PET index as well as a tool to compare with other climatic regions. 
PET ranges for summer were adapted for the tropical climatic context which showed higher ranges than the PET ranges developed for the sub-tropical context in Taiwan. With an $88 \%$ acceptability limit, the 'Neutral' range for PET was found to be between $29.5-32.5{ }^{\circ} \mathrm{C}$. However, the lower and lower extreme categories of PET ('Cool' and 'Cold') could not be verified as the study mainly focuses on summer discomfort. Overall, the findings of this study is helpful to understand the degree of effect of urban microclimate on outdoor comfort conditions in a tropical context. The understanding of microclimatic conditions in tropical context demonstrated by the detailed field measurements, can be used by urban planners, designers and architects for climate-responsive urban design. Application of this knowledge will aid in improving comfort in outdoor urban spaces subjected to heat-stress and thereby, enhancing resilience to climate change in the most vulnerable tropical cities like Dhaka. 


\section{Acknowledgements}

This paper is drawn from a $\mathrm{PhD}$ research funded by the Schlumberger Foundation 'Faculty for the Future Award' at the University of Cambridge, Department of Architecture.

\section{Bibliography}

Ahmed, K. S. (2003) 'Comfort in urban spaces: Defining the boundaries of outdoor thermal comfort for the tropical urban environments', Energy and Buildings, 35(1), pp. 103 110. doi: 10.1016/S0378-7788(02)00085-3.

Ahmed, T. et al. (2014) 'The MAL-ED cohort study in Mirpur, Bangladesh', Clinical Infectious Diseases, 59(Suppl 4), pp. S280-S286. doi: 10.1093/cid/ciu458.

Ali-Toudert, F. (2005) 'Dependence of Outdoor Thermal Comfort on Street Design in Hot and Dry Climate', Berichte des Meteorologischen Institutes der Universität Freiburg, Nr. 15(15). doi: ISSN 1435-618X.

Ali-Toudert, F. and Mayer, H. (2007a) 'Effects of asymmetry, galleries, overhanging facades and vegetation on thermal comfort in urban street canyons', Solar Energy, 81(6), pp. 742-754. doi: 10.1016/j.solener.2006.10.007.

Ali-Toudert, F. and Mayer, H. (2007b) 'Effects of Street Design on Outdoor Thermal Comfort', Sci.U-Szeged.Hu, 42(3), pp. 1553-1554. doi: 10.1016/j.buildenv.2005.12.013.

Andreou, E. (2013) 'Thermal comfort in outdoor spaces and urban canyon microclimate', Renewable Energy. Elsevier Ltd, 55, pp. 182-188. doi: 10.1016/j.renene.2012.12.040.

Bourbia, F. and Awbi, H. B. (2004) 'Building cluster and shading in urban canyon for hot dry climate Part 1: Air and surface temperature measurements', Renewable Energy, 29(2), pp. 249-262. doi: 10.1016/S0960-1481(03)00170-8.

Brager, G. S. and Dear, R. J. De (1998) 'Thermal adaptation in the built environment : a literature review', Energy and Buildings, 27, pp. 83-96. doi: 10.1016/S03787788(97)00053-4.

Charalampopoulos, I. et al. (2013) 'Analysis of thermal bioclimate in various urban configurations in Athens, Greece', Urban Ecosystems, 16(2), pp. 217-233. doi: $10.1007 / \mathrm{s} 11252-012-0252-5$.

Cheng, V. et al. (2012) 'Outdoor thermal comfort study in a sub-tropical climate: A longitudinal study based in Hong Kong', International Journal of Biometeorology, 56(1), pp. 43-56. doi: 10.1007/s00484-010-0396-z.

de Dear, R. (1987) 'Ping-pong globe thermometers for mean radiant temperatures', Heating and Ventilating Engineer and Journal of Air Conditioning, 60(681), pp. 10-11.

de Dear, R. J. and Fountain, M. E. (1994) 'Field Experiments on Occupant Comfort and Office Thermal Environments in a Hot-Humid Climate', ASHRAE Transactions, 100, pp. 457-474.

Eliasson, I. et al. (2007) 'Climate and behaviour in a Nordic city', Landscape and Urban Planning, 82(1-2), pp. 72-84. doi: 10.1016/j.landurbplan.2007.01.020.

Elnabawi, M. H., Hamza, N. and Dudek, S. (2016) 'Thermal perception of outdoor urban spaces in the hot arid region of Cairo, Egypt', Sustainable Cities and Society. Elsevier 
B.V., 22, pp. 136-145. doi: 10.1016/j.scs.2016.02.005.

Emmanuel, R. and Johansson, E. (2006) 'Influence of urban morphology and sea breeze on hot humid microclimate: the case of Colombo, Sri Lanka', Climate Research, 30(3), pp. 189-200. doi: 10.3354/cr030189.

Emmanuel, R., Rosenlund, H. and Johansson, E. (2007) 'Urban shading - a design option for the tropics? A study in Colombo, Sri Lanka', International Journal of Climatology, 4(September), pp. 1549-1555. doi: 10.1002/joc.

Fanger, O. (1970) Thermal Comfort Analysis and Applications in Environmental Engineering. New York: McGraw Hill.

Fong, C. S. et al. (2019) 'Holistic recommendations for future outdoor thermal comfort assessment in tropical Southeast Asia: A critical appraisal', Sustainable Cities and Society. Elsevier, 46(September 2018), p. 101428. doi: 10.1016/j.scs.2019.101428.

Givoni, B. (1998) Climate Considerations in Building and Urban Design, ,. John Wiley \& Sons.

Google Earth V 7.1.4.1529. (2015) Dhaka, Bangladesh.23 Deg 46'2.75" N and 90 Deg 25 '10.32" E, Eye alt $27.14 \mathrm{~km}$. Digital-Globe 2015. Available at: http://www.earth.google.com/ (Accessed: 20 April 2015).

Hirashima, S. Q. da S., Assis, E. S. de and Nikolopoulou, M. (2016) 'Daytime thermal comfort in urban spaces: A field study in Brazil', Building and Environment. Elsevier Ltd, 107, pp. 245-253. doi: 10.1016/j.buildenv.2016.08.006.

Höppe, P. (1999) 'The physiological equivalent temperature - a universal index for the biometeorological assessment of the thermal environment.', International journal of biometeorology, 43(2), pp. 71-75. doi: 10.1007/s004840050118.

Humphreys, M., Nicol, F. and Susan, R. (2015) Adaptive Thermal Comfort: Foundations and Analysis. Routledge.

Ignatius, M., Wong, N. H. and Jusuf, S. K. (2015) 'Urban microclimate analysis with consideration of local ambient temperature, external heat gain, urban ventilation, and outdoor thermal comfort in the tropics', Sustainable Cities and Society. Elsevier B.V., 19, pp. 121-135. doi: 10.1016/j.scs.2015.07.016.

ISO 7726 (1998) Ergonomics of the Thermal Environment - Instruments for Measuring Physical Quantities. Geneva.

Johansson, E. (2006) 'Influence of urban geometry on outdoor thermal comfort in a hot dry climate: A study in Fez, Morocco', Building and Environment, 41(10), pp. 13261338. doi: 10.1016/j.buildenv.2005.05.022.

Johansson, E. et al. (2018) 'Outdoor thermal comfort in public space in warm-humid Guayaquil, Ecuador', International Journal of Biometeorology. International Journal of Biometeorology, pp. 1-13. doi: 10.1007/s00484-017-1329-x.

Kikegawa, Y. et al. (2006) 'Impacts of city-block-scale countermeasures against urban heatisland phenomena upon a building's energy-consumption for air-conditioning', Applied Energy, 83(6), pp. 649-668. doi: 10.1016/j.apenergy.2005.06.001.

Köppen, W. P. (1931) Grundriss der Klimakunde. W. de Gruyter.

Krüger, E. et al. (2013) 'Urban heat island and differences in outdoor comfort levels in Glasgow, UK', Theoretical and Applied Climatology, 112(1-2), pp. 127-141. doi: 10.1007/s00704-012-0724-9. 
Krüger, E. L., Minella, F. O. and Rasia, F. (2011) 'Impact of urban geometry on outdoor thermal comfort and air quality from field measurements in Curitiba, Brazil', Building and Environment. Elsevier Ltd, 46(3), pp. 621-634. doi:

10.1016/j.buildenv.2010.09.006.

Li, K., Zhang, Y. and Zhao, L. (2016) 'Outdoor thermal comfort and activities in the urban residential community in a humid subtropical area of China', Energy and Buildings. Elsevier B.V., 133, pp. 498-511. doi: 10.1016/j.enbuild.2016.10.013.

Lin, T. P. (2009) 'Thermal perception, adaptation and attendance in a public square in hot and humid regions', Building and Environment. Elsevier Ltd, 44(10), pp. 2017-2026. doi: 10.1016/j.buildenv.2009.02.004.

Lin, T. P. and Matzarakis, A. (2008) 'Tourism climate and thermal comfort in Sun Moon Lake, Taiwan', International Journal of Biometeorology, 52(4), pp. 281-290. doi: 10.1007/s00484-007-0122-7.

Lin, T. P., Matzarakis, A. and Hwang, R. L. (2010) 'Shading effect on long-term outdoor thermal comfort', Building and Environment. Elsevier Ltd, 45(1), pp. 213-221. doi: 10.1016/j.buildenv.2009.06.002.

Matzarakis, A., Rutz, F. and Mayer, H. (2010) 'Modelling radiation fluxes in simple and complex environments: Basics of the RayMan model', International Journal of Biometeorology, 54(2), pp. 131-139. doi: 10.1007/s00484-009-0261-0.

McIntyre, D. A. (1980) Indoor climate. London : Applied Science Publishers.

Ndetto, E. L. and Matzarakis, A. (2017) 'Assessment of human thermal perception in the hothumid climate of Dar es Salaam, Tanzania', International Journal of Biometeorology. International Journal of Biometeorology, 61(1), pp. 69-85. doi: 10.1007/s00484-0161192-1.

Ng, E. and Cheng, V. (2012) 'Urban human thermal comfort in hot and humid Hong Kong', Energy and Buildings. Elsevier B.V., 55, pp. 51-65. doi:

10.1016/j.enbuild.2011.09.025.

Nikolopoulou, M., Baker, N. and Steemers, K. (2001) 'Thermal comfort in outdoor urban spaces: Understanding the Human parameter', Solar Energy, 70(3), pp. 227-235. doi: 10.1016/S0038-092X(00)00093-1.

Nikolopoulou, M. and Lykoudis, S. (2006) 'Thermal comfort in outdoor urban spaces: Analysis across different European countries', Building and Environment, 41(11), pp. 1455-1470. doi: 10.1016/j.buildenv.2005.05.031.

Nikolopoulou, M. and Lykoudis, S. (2007) 'Use of outdoor spaces and microclimate in a Mediterranean urban area', Building and Environment, 42(10), pp. 3691-3707. doi: 10.1016/j.buildenv.2006.09.008.

Nikolopoulou, M., Lykoudis, S. and Kikira, M. (2003) 'Thermal comfort in outdoor spaces: field studies in Greece', Proceedings of the fifth international conference on urban climate, Lodz, pp. 1-5.

Nikolopoulou, M. and Steemers, K. (2003) 'Thermal comfort and psychological adaptation as a guide for designing urban spaces', Energy and Buildings, 35(1), pp. 95-101. doi: Pii S0378-7788(02)00084-1 \nDoi 10.1016/S0378-7788(02)00084-1.

Oke, T. R. (1987) Boundary Layer Climates. Psychology Press.

Oke, T. R., Taesler, R. and Olsson, L. E. (1990) 'The tropical urban climate experiment 
(TRUCE)', Energy and Buildings, 15(C), pp. 67-73. doi: 10.1016/03787788(90)90117-2.

Pantavou, K. G., Lykoudis, S. P. and Nikolopoulos, G. K. (2016) 'Milder form of heat-related symptoms and thermal sensation: a study in a Mediterranean climate', International Journal of Biometeorology. International Journal of Biometeorology, 60(6), pp. 917929. doi: 10.1007/s00484-015-1085-8.

Pantavou, K. and Lykoudis, S. (2014) 'Modeling thermal sensation in a Mediterranean climate-a comparison of linear and ordinal models', International Journal of Biometeorology, 58(6), pp. 1355-1368. doi: 10.1007/s00484-013-0737-9.

Pickup, J. and de Dear, R. (2000) 'An outdoor thermal comfort index ( OUT-SET *) - Part I The model and its assumptions', (January 1999).

Potchter, O. et al. (2018) 'Outdoor human thermal perception in various climates: A comprehensive review of approaches, methods and quantification', Science of the Total Environment. Elsevier B.V., 631-632, pp. 390-406. doi: 10.1016/j.scitotenv.2018.02.276.

Rahman, M. Z., Siddiqua, S. and Kamal, A. S. M. M. (2015) 'Liquefaction hazard mapping by liquefaction potential index for Dhaka City, Bangladesh', Engineering Geology. Elsevier B.V., 188, pp. 137-147. doi: 10.1016/j.enggeo.2015.01.012.

Salata, F. et al. (2016) 'Outdoor thermal comfort in the Mediterranean area. A transversal study in Rome, Italy', Building and Environment. Elsevier Ltd, 96(October 2017), pp. 46-61. doi: 10.1016/j.buildenv.2015.11.023.

Santamouris, M. et al. (2001) 'On the impact of urban climate on the energy consumption of buildings', Solar Energy, 70(3), pp. 201-216. doi: 10.1016/S0038-092X(00)00095-5.

Sharmin, T., Steemers, K. and Matzarakis, A. (2015) 'Analysis of microclimatic diversity and outdoor thermal comfort perceptions in the tropical megacity Dhaka, Bangladesh', Building and Environment. Elsevier Ltd, 94(November), pp. 734-750. doi: 10.1016/j.buildenv.2015.10.007.

Spagnolo, J. and de Dear, R. (2003) 'A field study of thermal comfort in outdoor and semioutdoor environments in subtropical Sydney Australia', Building and Environment, 38(5), pp. 721-738. doi: 10.1016/S0360-1323(02)00209-3.

Taleghani, M. et al. (2014) 'Outdoor thermal comfort within five different urban forms in the Netherlands', Building and Environment. Elsevier Ltd, 83, pp. 65-78. doi: 10.1016/j.buildenv.2014.03.014.

Thorsson, Sofia et al. (2007) 'Different methods for estimating the mean radiant temperature in an outdoor urban setting', International Journal of Climatology, 1993(October), pp. 1983-1993. doi: 10.1002/joc.

Thorsson, S. et al. (2007) 'Thermal Comfort and Outdoor Activity in Japanese Urban Public Places', Environment and Behavior, 39, pp. 660-684. doi: $10.1177 / 0013916506294937$.

Thorsson, S., Lindqvist, M. and Lindqvist, S. (2004) 'Thermal bioclimatic conditions and patterns of behaviour in an urban park in Goteborg, Sweden', International Journal of Biometeorology, 48(3), pp. 149-156. doi: 10.1007/s00484-003-0189-8.

Tsitoura, M., Tsoutsos, T. and Daras, T. (2014) 'Evaluation of comfort conditions in urban open spaces. Application in the island of Crete', Energy Conversion and 
Management. Elsevier Ltd, 86, pp. 250-258. doi: 10.1016/j.enconman.2014.04.059. Villadiego, K. and Velay-Dabat, M. A. (2014) 'Outdoor thermal comfort in a hot and humid climate of Colombia: A field study in Barranquilla', Building and Environment, 75, pp. 142-152. doi: 10.1016/j.buildenv.2014.01.017.

$\mathrm{Xi}$, T. et al. (2012) 'Study on the outdoor thermal environment and thermal comfort around campus clusters in subtropical urban areas', Building and Environment. Elsevier Ltd, 52(July 2007), pp. 162-170. doi: 10.1016/j.buildenv.2011.11.006.

Yahia, M. W. and Johansson, E. (2013) 'Influence of urban planning regulations on the microclimate in a hot dry climate: The example of Damascus, Syria', Journal of Housing and the Built Environment, 28(1), pp. 51-65. doi: 10.1007/s10901-0129280-y.

Yang, W., Wong, N. H. and Jusuf, S. K. (2013) 'Thermal comfort in outdoor urban spaces in Singapore', Building and Environment. Elsevier Ltd, 59, pp. 426-435. doi: 10.1016/j.buildenv.2012.09.008.

Yang, W., Wong, N. H. and Zhang, G. (2013) 'A comparative analysis of human thermal conditions in outdoor urban spaces in the summer season in Singapore and Changsha, China', International Journal of Biometeorology, 57(6), pp. 895-907. doi: 10.1007/s00484-012-0616-9.

Zacharias, J., Stathopoulos, T. and Wu, H. (2001) 'Microclimate and Downtown Open Space Activity', ENVIRONMENT AND BEHAVIOR, 33(2), pp. 296-315. doi: 10.1177/0013916501332008.

Zacharias, J., Stathopoulos, T. and Wu, H. (2004) 'Spatial Behavior in San Francisco's Plazas: The Effects of Microclimate, Other People, and Environmental Design', Environment and Behavior, 36(5), pp. 638-658. doi: 10.1177/0013916503262545. 